\section{NU UNA Kastamonu Eğitim Dergisi Kastamonu Education Journal}

Eylül 2019 Cilt:27 Sayı:5

kefdergi.kastamonu.edu.tr
Başvuru Tarihi/Received: 09.01.2019

Kabul Tarihi/Accepted: 16.02 .2019

DOI: 10.24106/kefdergi.3521

\title{
Okul-dışı Öğrenmeye Yönelik Öğretmen Mesleki Gelişim Programından Mentorlük Desteği Alan Öğretmenin Öğrencilerine Yansıyan Etkileri- Bir Örnek Olay Çalışması
}

\section{The Impacts of A Teacher Who Received Mentorship Support from A Teacher Professional Development Program for Informal Learning on Students' Reflections - A Case Study}

\section{Öz}

\author{
Ceyhan ÇiĞDEMOĞLU1 ${ }^{1}$ Ayşegül TEKELLi², Fitnat KÖSEOĞLU³
}

Bu çalışmanın amacı, bilim merkezleri gibi okul dışı öğrenme ortamlarının imkânlarını okul müfredatına etkili bir şekilde entegrasyonunu destekleyen BILMER (bilim merkezlerine yönelik mesleki gelişim projesinin kısa kullanımı) projesi eğitimlerine katılmış bir öğretmenin, öğrencileri ile yürüttüğü proje tabanlı öğrenme sürecinde proje ekibinden aldığı mentorlük desteğinin öğrencilerine ve kendisine yansıyan etkilerini ortaya çıkarmaktır. Bu çalışmada örnek olay yöntemi kullanılmış; veriler öğretmen ve öğrencilerinden nitel yollarla toplanmıştır. Çalıştaya katılan kimya öğretmeni proje ekibinden aldığı mentorlük süresince izlenmiş ve öğrencileri ile yürüttükleri projeler sırasında gözlemlenmiştir. Verilerin analiziyle, öğrencilerin proje tabanlı öğrenme sürecindeki görüşleri ve kazanımları ortaya çıkartımıştr. Bulgular, öğrencilerin kavramsal, duyuşsal, bilimin doğası ile ilgili anlayışlar, disiplinler arası ilişkiler ve çevreye duyarlıı̆̆ı gibi konularda önemli kazanımlar edindiğini ortaya koymuştur. Ayrıca, öğrenci günlüklerinden elde edilen veriler öğrencilerin kariyer planlamalarının, hatta meslek seçimlerinin ve geleceğe bakış açılarının değiştiğini göstermiştir. Bu araştırmanın sonuçlarına dayanarak, öğretmenlere sunulacak mesleki gelişim eğitimlerinin etkili ve sürdürülebilir olabilmesi için mesleki gelişim programlarına katllan öğretmenlere mentorlük desteğinin de sağlanmasının önemli olduğu tespit edilmiştir.

Anahtar Kelimeler: öğretmen mesleki gelişimi, mentorlük, proje tabanlı kimya öğretimi, okul dışı öğrenme ortamları.

\section{Abstract}

The aim of this study is to reveal the effects of a mentoring process on a teacher who has participated in BILMER (abbreviation of the project that develops a professional development program for science centers) project workshops which support the integration of extracurricular learning environments such as Science Centers into school curricula, and the effect of the mentoring process regarding project-based learning over the students. In this study, case study method was used; data were collected from the teacher and her students through qualitative tools. The chemistry teacher who participated in the workshop was followed during the mentoring period and she was observed during the projects-based activities conducted with the students. Data analysis reveals students' views regarding the projects based learning and their gains concerning the process. Findings indicate that students have achieved significant gains in terms of conceptual aspects, affective aspects, and understanding of the nature of science, interdisciplinary aspects, and awareness about the environment. In addition, data gathered from student diaries showed that students' career planning, even career choices and their future perspectives have changed after the implementation. Based on the findings, the importance of providing mentorship support to teachers in professional development programs is stressed from many aspects, so that it can be ensured that professional development programs to be offered to teachers are effective and sustainable.

Keywords: teachers' professional development, mentoring, project-based chemistry learning, informal learning environments

1. Atılım Üniversitesi, İşletme Bölümü, Ankara, Türkiye; https://orcid.org/0000-0001-5389-5790

2. Milli Eğitim Bakanlığı, Kimya Öğretmeni, Ankara, Türkiye;

3. Gazi Üniversitesi, Eğitim Fakültesi, Ankara, Türkiye; https://orcid.org/0000-0003-2437-6515

Atıf / Citation: Çiğdemoğlu, C., Tekeli, A. \& Köseoğlu, F. (2019). Okul-dışı öğrenmeye yönelik öğretmen mesleki gelişim programından mentorlük desteği alan öğretmenin öğrencilerine yansıyan etkileri- bir örnek olay çalışması. Kastamonu Education Journal, 27(5), 2311-2330. doi:10.24106/ kefdergi.3521 


\section{Extended Abstract}

Purpose: Although the components of teachers' professional development programs regarding informal learning environments vary, it is noteworthy to state that the programs including collaborative hands on activities and providing opportunities to work with scientist or institutes of higher education are more effective. Mentoring is perceived to be one of the main themes of Professional development models (Sparks and Loucks-Horsley, 1989; Drago-Severson, 1994). Specifically, Laverick (2016) emphasizes that a qualified professional development can only be possible if faculty members are mentored by teachers, while Guskey (2000) points out that higher education institutions should cooperate with schools in the area of professional development. As a product of a project that develop professional development program for informal learning environments, this study investigates the effect of mentoring process about project based learning on a teacher who participated in a series workshops that are organized to support the integration of extracurricular learning environments and methods of teaching regarding these environments and the effect of this mentoring process on students' gains.

Method: In this study, a qualitative case study research design was used. The teacher and her two volunteer students were purposively selected as the participants of the study. The mentor was the coordinator of the project; she was a science education professor with an experience of almost forty years. The chemistry teacher has been teaching chemistry since 2002 at various public schools. She volunteered to take part in the first workshop of the project and has a master's degree in chemistry education. The teacher has almost 14 years of experience in the field. The gender of mentor, teacher, and participating students were all female. The students are 10th grade, attending a state high school; Semra (nickname) and Elif (nickname) participated as volunteer. They are not experienced in project preparation and project execution before this study. The workshop that the teacher has participated was composed of nine different modules, including nature of science, teaching and learning in informal settings, science society communication ect. The teacher and the mentor meet regularly about project-based learning. Teacher crated a project class and selected those two volunteer students. The mentoring process lasted 20 weeks. The students used the laboratory of a well-known hospital for their investigations. The data collection tools included interview with the teacher, interviews with the students, students' diaries, and teacher' and mentors' analytical memos (field notes). The data was analyzed qualitatively based on its content. First codes, then themes are emerged.

Findings: The findings are given in two different themes; the first about students' gains, the second as the interaction between the mentor and the teacher and the teacher' gain. Students' gains were categorized in five main aspects; conceptual, affective, understanding of the nature of science, interdisciplinary relationship and awareness about the environmental issues. Students took responsibility for learning concepts and reached meaningful learning by experiencing a process of conceptual change through the project-based implementation. Based on teacher notes and interviews, students' attitudes and interest towards chemistry and science have been positively affected. They started to be more active in lessons and they were more enthusiastic in involving in the lesson. Students have experienced that there is no way and method of doing scientific investigation and scientific knowledge, they also experienced the how scientist do science. Before starting the project, students began to work without knowing what method they would use and what answers they would reach at the end of the investigation. In other words, the students had an open-ended inquiry process in their investigation which is similar to that of the real case conducted by scientist. The students investigated concepts from to different disciplines during the project-based chemistry implementation. They noticed that there is no single area with sharp borders in the solution of real life problems; rather they have realized that different disciplines such as chemistry-biology-mathematics are somehow integrated in a cognitive level. Finally, there are evidences to support that students' environmental awareness have increased after the implementation. They investigated the hazards of chemical wastes, they wrote their opinions on their diaries concerning environmental problems given in the media. Students tried to determine the detergent usage rates by preparing questions to their families and their social environment to increase awareness.

Teacher also benefited from the process; she stated that the support she received from the mentor in reaching the above-mentioned gains is unimaginable. As Baki and Tümer (2009) explained, one of the most important problems of the project-based teaching process is that teachers have problems in guiding their students, the teacher claimed that though mentoring she could easily guide her students. In addition, teacher stated the difficult of designing effective projects that attract students' attention and to control each phase of the project. She stressed that he was very pleased to be able to overcome such problems easily thanks to the mentoring support she received. In addition, teacher mentioned about problems about obtaining and the cost of providing the necessary tools and equipment in designing project with students; she stressed how easily she could overcome this problem with the help of the mentoring.

Conclusion and Discussion: It can be concluded that both teacher and students benefited from the mentoring process on project-based learning in informal contexts. Through mentoring, the teacher was able to implement the knowledge she has acquired from the workshops by guidance of her mentor, and also she was able to overcome possible drawbacks of projects-based learning reported in the literature. Similar to conclusions drawn by James et al. (2018), in this study, both teacher and students have been supported in cognitive and affective domains, their self- confidence have increased throughout the process. The conclusion regarding increase in students' enthusiasm is in line with Mukeredzi (2017). Based on the findings, we can also conclude that to achieve the objectives of a professional development programs for teachers, as in the BILMER Professional Development Model, it is necessary to include a module that includes mentoring so that the professional development programs may be more sustainable. The limitations of this study include mentoring only one teacher and especially two students of that teacher. Future studies may compare practices of teachers who do not take mentoring support and teachers who take it. As a result, this study provides empirical evidences concerning positive effect of mentoring support in a project-based chemistry implementation both on teacher and her two students.

| Kastamonu Eğitim Dergisi, 27(5), 2019 | 


\section{Giriş}

Öğretmen eğitiminde mesleki gelişimin oldukça önemli bir yer tutar. Fen alanı öğretmenlerinin mesleki gelişimleri üzerine yapılan araştırmalar, son on yıl içinde belirgin bir noktaya gelmiş ve kapsamlı kuramsal çerçeveler oluşturulması üzerinde tartşmalara ilgi artmıştır (Avraamidou, 2014). Öğretmenlerin gelişiminin kavramsallaştrılmasında farklı yönleri ön planda tutan araştrrmalar, genellikle: öğretmenlerin bilgi düzeylerine (Avraamidou ve Zembal-Saul, 2010), bilimin doğası ve bilimsel araştırma anlayışlarına (Akerson, Abd-El-Khalick ve Lederman, 2000), pedagojik alan bilgilerine ve inançlarına (Friedrichsen, van Driel ve Abell, 2010), ayrıca müfredat hakkındaki bilgilerine (Forbes ve Davis, 2008) odaklanmıştr. Ancak, öğretmenlerin gelişimine ilişkin kapsamlı çerçevelerin ve modellerin büyük çoğunluğunda, sadece okul içi öğrenme ortamlarının esas alındığı görülmektedir.

Okul dışı öğrenme ortamlarına yönelik öğretmen mesleki gelişim programları, okullarda yürütülen programlara kıyasla kısmen daha sınırlıdır. Bilim merkezleri, müzeler ve akvaryumlar gibi okul dışı öğrenme ortamları, fen eğitiminde müfredat hedeflerine ulaşılmada büyük bir öneme sahiptir; çünkü bu ortamlar, okul içi fen öğrenimini tamamlamak ve genişletmek, bilimsel okur yazarlığı geliştirmek ve halkın bilime yönelik anlayışını arttırmak için uygun ortamlardır (Gutwill ve Allen, 2012; Feinstein ve Meshoulam, 2014). Okul dışı öğrenme ortamlarına yönelik mesleki gelişim programları daha çok fen bilimleri ile ilgili alan bilgisine (Duran ve Ballone-Duran, 2005), araştırma sorgulamaya dayalı pedagojilere (Duran ve Ballone-Duran, 2005; Astor-Jack, McCallie, Balcerzak, 2007) ve bilimsel sorgulamaya (Akerson, Abd-El-Khalick, ve Lederman, 2000; Gutwill ve Allen, 2012) odaklanmaktadır.

Okul dışı ortamlara özgü mesleki gelişim program bileşenleri farklılık gösterse bile genel olarak bu amaçla sunulan 'Öğretmen Mesleki Gelişim' programlarında, öğretmenlere sunulan ellerim iş başında ve bilim insanları ile birlikte çaıışma imkânları dikkat çekmektedir. Bu tarz mesleki gelişim programları, öğretmenlerin bilimsel içeriği öğrenmelerinin yanında fen öğretimine yönelik tutumlarının da gelişmesini sağlamaktadır (Pecore, Kirchgessner ve Carruth, 2013). Rhodes ve Beneicke (2002) öğretmenlerin mesleki gelişimleri için meslektaşlarının resmi ve gayrı resmi olarak birbirlerine sağladığı desteğin gerekliliği üzerinde durur. Benzer şekilde, Sparks ve Loucks-Horsley (1989) ve Drago-Severson (1994) tarafindan yapılan incelemelerde, mesleki gelişim (MG) modellerinin ana temalarından birinin de rehberlik (mentoring) faaliyetleri olduğu görülmektedir. Çoğu MG modeli pedagojinin önemini ve özellikle araştrma-sorgulama ve proje tabanlı tekniklerin gerekliliğini vurgular (National Reaserach Council: NRC, 1996, 2000). Bu gereklilikler dışında, Strong, Silver ve Perini (2001) öğretmen gelişiminin ana odak noktasında öğrencilerin olması gerektiğini ileri sürer ve öğrencilerin öğrenmesinde gerçek iyileşmeyi görmenin tek yolunun öğretmenlerin eğitimini öğrencinin öğrenmesine bağlamakla mümkün olabileceğini savunur. Bu noktada, Loucks-Horsley ve Matsumoto (1999) ise, öğretmen gelişiminin sadece öğrenci puanlarını arttırmaktan ziyade, çok daha fazla şeyler barındırdığına dikkat çekmektedir. Örneğin, öğretmenlerin bilgi ve uygulamalarındaki değişim, onların liderlik becerilerini geliştirerek öğrencilerinde çeşitli yönlerden olumlu yönde değişime neden olacağı için öğretmen gelişimi önemlidir.

Okul dışı öğrenme ortamlarının, öğrencilerde bilime yönelik olumlu tutum geliştirdiğine dair çalışmalar vardır (Falk ve Dierking, 1997; Pace ve Tesi, 2004). Öğretim programı içerisine sınıf gezilerinin dâhil edilmesi, öğrencilerin bilime yönelik tutumlarını olumlu yönde etkileyebilir (Osborne, Simon ve Collins, 2003). Nitekim birçok araştrma öğrencilerin tüm sınıf gezisi türlerine karşı tutumlarının olumlu yönde olduğunu (Falk ve Dierking, 1997; Pace ve Tesi, 2004) göstermektedir. Şentürk ve Özdemir'in (2014) yaptığı çalışma da, benzeri şekilde Orta Doğu Teknik Üniversitesi Uygulamalı Bilim Merkezi'nin öğrencilerin bilime yönelik tutumlarını artırdığını ve bu artı̧ın öğrencilerin cinsiyetinden, sınıf seviyesinden ve fen ve teknoloji dersindeki başarılarından bağımsız olduğunu göstermiştir. Öğretmenlerin bilime yönelik tutumlarının ya da öğretmeye yönelik inançlarının öğrencilerin öğrenme ve tutumlarına etki ettiği alan yazında belirtilmektedir (Kirikkay, 2009; Miranda, 2012). Bunların ötesinde, öğretmen mesleki gelişiminin öğrencilerinin başarılarına yansıyarak çeşitli yönlerden etkisi olduğu birçok araştırmada raporlanmıştır (Blank, de las Alas ve Society for Research on Educational Effectiveness, 2010). Bu yüzden öğretmenlerin bilimsel içerik, pedagoji, tutum konularında geliştirilmeleri sadece sınıftaki performanslarını değil, aynı zamanda öğrencilerinin bilimsel içeriğe ve bilime yönelik tutumlarını da olumlu yönde etkileyebilir (Pecore, Kirchgessner ve Carruth; 2013).

Mentorlük geleneksel olarak başkalarının becerilerini, bilgilerini veya yeteneklerini geliştirmeyi amaçlayan bir ilişki süreci olarak tarfilenir (Hansford, Ehrich ve Tennent, 2004). Bu süreçte uzun süreli etkileşim, gözlem, danışma, geri bildirim ve değerlendirme gibi kişilerin gelişim ihtiyacını karşılama durumu söz konusudur. Harrison, Dymoke ve Pell, (2006) mentorlüğün öğretmen eğitiminde öğrenci merkezli yaklaşımların egemen olmasında ve iyi öğretim uygulamalarının gözlenebilmesini sağlamada önemli olduğunu vurgulamaktadır. Eğitim açısından bakıldığında mentorlük, deneyimli ve özel hazırlanmış bir eğitimcinin, deneyimsiz ya da daha az deneyimli bir öğretmenle iş birliğine dayalı yargısız olarak çaıışması ve sınıftaki öğretim yöntemlerinin iyileştirilebilmesi için kasıtlı olarak çalışarak öğretimin gelişimini kolaylaştıran 
bir süreçtir. Kısaca bu sürecin öğretmen kalitesini geliştirdiği söylenebilir. Ulusal bağlamda mentorlük sürecinin öğretmen eğitimindeki önemini vurgulayan pek çok araştırma vardır (bakınız: Akçamente, Aslan ve Dinçer, 2010; Aslan ve Öcal, 2012; Kartal, Özdemir ve Yirci, 2017; Sezgin, Koşar ve Er; 2014). Akçamente vd. (2010) mentorlüğü, bir meslek alanında tecrübeli olan birinin daha az tecrübeli olan kişiye yardım etmesi olarak tarif eder. Mentorlüğün akıl hocalığı olduğunu belirten araştırmacılar da vardır (Akçamente, Aslan ve Dinçer, 2010; i̇lğan, 2013; Yıldırım ve Yılmaz, 2013). Mentorlük, bireylerin mesleğinin ya da kurumunun amaçlarını nitelikli olarak yerine getirebilmek için destek alınılan daimi bir süreç olarak da tarif edilmektedir (Daresh, 2003). Ayrıca bu kavramı, Yıldırım ve Yılmaz (2013) farklı tip ilişkiler içinde tarif etmişlerdir. Örneğin, "mesleğinde tecrübeli ve deneyimli olan yöneticilerin mesleğinde yeni olan yöneticilere ve öğretmenlere; mesleğinde tecrübeli ve deneyimli müfettişlerin mesleğinde yeni olan müfettişlere, yöneticilere ve öğretmenlere; mesleğinde tecrübeli ve deneyimli öğretmenlerin mesleğinde yeni olan öğretmenlere ve öğrencilere tecrübe ve bilgi birikimlerini sistemli olarak aktarması" (s.100) şeklinde açıklamışlardır. Akçamente vd. (2010), mentor ve öğretmen arasındaki ilişkinin belirli bir plan ve program kapsamında hazırlandığını, gelişigüzel olamadığını ifade eder.

Laverick (2016), nitelikli bir mesleki gelişimin fakülte üyelerinin öğretmenlere mentorlük yapması ile mümkün olabileceğini vurgularken, Guskey (2000) mesleki gelişim konusunda yükseköğretim kurumlarının okullarla işbirliği içinde olması gerektiğini söyler. Guskey ayrıca, mesleki gelişim eğitimlerinin genellikle çalıştaylarla sınırı kaldığını, devamında yükseköğretim kurumlarının mentorlük koçluk gibi destek mekanizmaları ile öğretmen gelişimini sürdürmesi gerektiğini savunmaktadır. Maurer (2000) de, mesleki gelişimin birincil odak noktasının nihai olarak öğrenci öğrenmesini iyileştirmek olduğunu ve bunun da yalnızca sürekli eğitim ve gelişim ile elde edilebileceğini vurgulamaktadır. Bu çalışmada, öğretmen niteliğini artırmak için tüm bu hususlar dikkate alınarak TÜBiTAK (Türkiye Bilimsel ve Teknolojik Araştırma Kurumu)-1001 araştırma projesi kapsamında desteklenen BiLMER Mesleki Gelişim Programı (Köseoğlu, 2018) ile verilen eğitim çalıştayına katılan gönüllü bir öğretmenle BiLMER Modeli kapsamında yürütülen mentorlük sürecinin, öğretmenin çeşitli yönlerden desteklenmesinin uygulamalarına nasıl yansıdığı ve bu uygulamaların öğrencileri üzerindeki etkisi araştırılmıştır. Bu araştırmada, öğretmen mesleki gelişim programına katılan öğretmenle, BiLMER Mesleki Gelişim Modeli çerçevesinde mesleki bilgi ve deneyimlerini paylaşarak ona özellikle çeşitli öğretim yaklaşımları ve bilimsel yöntem konusunda destek sağlayan akademik kişiye mentor denmiştir.

\section{Kuramsal Çerçeve}

Mesleki gelişimle ilgili güncel araştırmalarda "geleneksel" mesleki gelişim yaklaşımları eleştirilmekte ve daha işbirlikçi Mesleki Gelişim (MG) modelleri savunulmaktadır (Scott ve Weeks, 1996; Simmons vd., 2000; Stein vd., 1999). Geleneksel modellerde öğretmenlere eyleme dönüştürmesi istenilen bilgi ve kaynaklar sunulurken bilginin yaygınlaştırılmasına yönelik yukarıdan aşağıya bir yaklaşımla tek seferlik çalıştaylar düzenlenir (Gersten, Vaughn, Deshler ve Schiller, 1997). Buna karşılık işbirlikçi modellerde, öğretmenler yeni fikirler dener; öğrenme-öğretme faaliyetlerini otantik etkinlikler üzerinden birlikte inşa ederler (Borko ve Putnam, 1998). İşbirliğine dayalı çeşitli bağlamlarda mesleki gelişimi destekleyen modellerde, öğrenme sosyal yapılandırıcı kuramın öngördüğü ilişkiler çerçevesinde şekillenmektedir. İnsan sosyal bir varlık olduğu için sosyal etkileşimlerin rolü yadsınamaz. Genellikle Vygotsky'e (1978) atfedilen sosyal öğrenme kuramı da, öğrencilerin yeni bir bilgiyi öğrenirken daha bilgili arkadaşlarıyla ya da öğretmenleriyle kurdukları iletişimin önemine vurgu yapmaktadır. Okul dışına yapılan sınıf gezileri veya bilim şenliklerine katılmak bu tür iletişimlerin kurulması için imkânlar sağlamaktadır. Bunların ötesinde, mesleki gelişim modellerinde genellikle öğretmen ve öğrenci davranışlarında değişiklik beklendiği için bu modeller, Ajzen'nin (1985) planlı davranış kuramından ve ayrıca öğrenmenin sosyokültürel bir etkinlik olarak tasvir edildiği etkinlik kuramından (Cole, 1996; Scribner, 1984; Wertsch, 1985) beslenmektedir. Bu araştırmada söz konusu öğretmenin mentorlük sürecinde eğitim aldığı BiLMER mesleki gelişim modeli, bu kuramlara dayanarak tasarlanmıştır.

Etkinlik kuramı, öğrenenin objeler ve olaylarla etkileştiğini bu nedenle onlara ait özelliklere dair anlayış kazandığını da varsayar. Burada sunulan araştırma, BILMER mesleki gelişim modeli kapsamında verilen mentorlük eğitiminin, öğretmenin çeşitli öğrenme ortamlarını ve objeleri uygun öğrenme yaklaşımlarını kullanarak derslerine entegre etmesini sağlayacağı ve bunun da öğrencilerinin öğrenmelerini çeşitli yönlerden olumlu yönde etkileyeceği varsayımını destekleyecek bulgular elde etmek amacıyla yürütülmüştür. Nitekim pek çok araştırmada, öğrencinin öğrenmesinde, öğretmenlerin diğer okul faktörlerine oranla daha önemli olduğu belirtilmekte ve özellikle kaliteli mesleki gelişim programlarının ve mentorlük süreçlerinin öğretmenin uygulamalarını değiştirme ve öğrenci öğrenmesini olumlu yönde etkileme potansiyeline sahip olduğu vurgulanmaktadır (Huling ve Resta, 2001; Fricke, Horak, Meyer ve Van Lingen, 2008). Ayrıca, proje-tabanlı öğretim konusunda öğretmenlerin öğrencilerine rehberlik etmede desteğe ihtiyaç duydukları (Baki ve Bütüner, 2009; Marx vd., 1997; Thomas, 2000) bilinmektedir. Etkili mesleki gelişime yüklenen anlam, öğretmenleri destekleyici faaliyetleri kapsaması; onlara öğretim odaklı, işbirlikçi ve süreklilik arz eden öğrenme firsatları sunmasıdır. Bu nedenlerle, BiLMER MG mo- 
deli çerçevesinde bir öğretmenle yürütülecek mentorlük sürecinin, öğretmenin pedagojik deneyimlerinin öğrencilerine nasıl yansıdığını araştırmak bu çalışmanın kapsamını oluşturmuştur. Özellikle öğretmenin proje tabanlı öğretim ile ilgili mentorlük desteği almak istemesiyle, bu sürecin öğrencileri bilişsel ve duyuşsal yönlerden nasıl etkilediğini incelemenin önemli olacağı düşünülerek uzun soluklu bir çalışma sürecine girilmiştir. Öğretmenin aldığı mentorlük sayesinde öğrencileri ile özgün projeler tasarlaması, öğretmen ve öğrencilerinin mesleki gelişim çalıştayından sonra takip edilmesi bu çalışmayı özgün kılmaktadır. Bu örnek olay araştırmasının şekillenmesini sağlayan araştrma sorusu, "BíLMER Mesleki Gelişim programına katılan bir öğretmenin BíLMER Modelinin teorik çerçevesi kapsamında aldığı uzun soluklu (20 haftalık) mentorlük destek süreci öğretmeni ve proje-tabanlı kimya uygulaması sürecinde öğrencilerini nasıl etkilemiştir?” şeklindedir.

\section{Yöntem}

Bu çalışmada nitel araştırma yaklaşımı benimsenmiştir. Nitel araştırma yöntemlerinden örnek olay (durum) araştırma stratejisi kullanılmıştır. Örnek olay çalışmaları, alan yazında etnografik veya katılımcı gözlem türü çalışmalarla karıştırılabilmektedir, bunun nedeni dayandıkları varsayımların benzerlik göstermesidir. Diğer nitel yöntemlerde olduğu gibi örnek olay çalışması bir sınıf, mahalle, bir kurum gibi doğal bir çevrede geçekleşir; araştırmanın odaklandığı konu ortamında ve olaylara bütüncül bakarak yorumlar yapılır. Neuman (2006), nitel araştırmada fikirler ve kanıtların karşılıklı olarak birbirine bağlı olduğunu, bunun özellikle örnek olay analizinde geçerli olduğunu ifade eder. Örnek olay belirleme, genellikle projelerin herhangi aşamasında ortaya çıkabilir, ancak Neuman (2006) bunun daha ziyade proje başında ya da sonunda gerçekleştiğini belirtmiştir.

\section{Çalışma Grubu: Mentor, Mentorlük Hizmeti alan Öğretmen ve Öğrencileri}

Bu nitel araştırmada "amaçlı örneklem" kullanılmıştır, çünkü temel amaç, araştırmanın konusunu oluşturan kişi, olay ya da durum hakkında ve belirli bir amaç doğrultusunda derinlemesine bilgi toplamaktır (Neuman, 2006). Bu örnek olay araştrrmasında, mentorlük sürecinin nasıl işlediği ve mentorün öğretmeni hangi yönlerden ve nasıl desteklediği de doğrudan araştırmanın sonucunu etkileyecek bir değişken olduğundan, mentorün de özelliklerinin belirtilmesi önemlidir. Çalışmada, Mentor projenin yürütücüsü olan öğretim üyesidir ve öğretmene katıldığı eğitim çalıştayından sonra düzenli olarak mentorlük desteği vermiştir. Sahasında kırk yılı aşkın deneyimi ile kimya/fen eğitimi/öğretiminde alanında saygın yeri olan bir kadın öğretim üyesidir. Öğretim yöntemleri, bilimin doğası, pedagojik alan bilgisi ve ayrıca analitik kimya alanında çok sayıda bilimsel çalışması ve kitapları vardır.

Öğretmen, 2002 yılından beri çeşitli devlet okullarında kimya öğretmenliği görevi yapmıştr. Projenin ilk uygulama çalıştayına gönüllü olarak katılmış, kimya eğitimi alanında yüksek lisans derecesine sahiptir. Alanında 14 yıllık deneyimi olan öğretmenin cinsiyeti kadındır. Daha önce de aynı proje yürütücüsünün yürüttüğü bilimin doğası ve öğretimi ile ilgili bir mesleki gelişim programındaki çalıştaya da gönüllü olarak katılmıştır. Öğretmen mentorlük sürecinde özellikle proje tabanlı kimya öğretimi konusunda mentorlük almak istediğini belirterek bu süreçte öğrencilerine kimya ile ilgili projeler yaptrrmayı tercih ettiğini belirtmiştir.

Öğrenciler, bu çalışmaya katılan iki kız öğrenci de bir devlet lisesinde öğrenim gören 10. Sınıf öğrencileridir. Semra (birinci öğrencinin rumuzu) ve Elif (ikinci öğrencinin rumuzu) projeye gönüllü olarak katılmıştır. Öğrenciler, bu çalışmadan önce proje hazırlama ve proje yürütme konusunda deneyimli değildir. Topluluk karşısında herhangi bir sunum ve etkinliğe katılma konusunda da deneyimleri sınırlıdır. Öğrenim gördükleri devlet lisesi, diğer liselere kıyasla daha düşük yüzdelik dilimle öğrenci kabul etmektedir. Öğrencilerin ortaöğretime geçiş sınavlarında yaptıkları fen sorularından doğru soru sayısı, Türkiye fen bilimleri doğru sayı ortalamasının altındadır. Öğretmenin alan notları öğrencilerin fen eğitimine yönelik olumlu tutumlar sergilemediklerini düşündürmektedir. Öğrenciler proje çalışmalarına 10. sınıfin 1. döneminde katılmışlardır.

\section{Öğretmenin Katıldığı BíLMER Mesleki Gelişim Projesi Çalıştayı;}

Mesleki Gelişim modellerinin ana temalarında eğitim (training), gözlem, değerlendirme, çalışma grupları (işbirlikli öğrenme), rehberlik (mentorlük), aksiyon (eylem) araştırması ve bireye özel rehberlenmiş (individually guided activities) faaliyetler bulunur (Sparks ve Loucks-Horsley 1989; Drago-Severson, 1994). Bilim Merkezlerine Yönelik Öğretmen ve Eğitmen Mesleki Gelişim Projesi kapsamında geliştirilen BILLMER MG Modeli, bu ana temalar dikkate alınarak geliştirilmiş ve öğretmenlere sunulan hedefler belirli modüller altında toplanmıştır. BILLMER modülleri kapsamında Proje süresince çok sayıda çalıştay düzenlenmiştir. Bu araştırmadaki katılımcı öğretmenin gönüllü olarak katıldığı proje çalıştayı, Gazi Eğitim Fakültesinde düzenlenen bir hafta 36 saat süren bir mesleki gelişim çalıştayıdır. Öğretmenin ne tür bir eğitime katılığını açıklamak amacıyla, Tablo 1 de bu çalıştayda yapılan bazı etkinlik isimleri ve bunların ilgili oldukları BíLMER modülleri verilmiştir. Bu çalıştay da dâhil BILLMER çalıştaylarında, yapılandırıcı yaklaşım zemininde, davranışçlık, keşfederek öğrenme gibi öğrenme teorileri de bütünleştirerek modüllerle ilgili eğitimler yürütülmüş; öğretmen- 
lerde değişiklik olup olmadığı, ön-son testler, tasarlanan ders planlarının incelenmesi, öğretmenleri okullarında takip edilerek gerekirse onları yeni eğitim toplantı ve çalıştaylarına davet ederek ölçülmeye, değerlendirilmeye çalışılmıştır. Kullanılan ölçme araçlarının yanı sıra, öğretmenlerin sınıf içi uygulamalarını, deneyimlerini, çalıştaylara gönüllü katılarak aktarmaları, modüllerin etkinliği konusunda somut veri sağlamıştr.

Katılımcı ögrretmenin, çalıştaydan sonra yürütülen mentorlük sürecinde aldığı eğitim ise kendi talebi çerçevesinde daha çok, okul dışı ortamlarda öğrenme teorileri ve proje tabanlı öğrenme gibi öğretim yaklaşımları, bilim nedir, bilimin doğası ve bilim öğretimi gibi yine BiLMER Modülleri kapsamında bulunan konularla ilgili olmuştur.

Tablo. 1 Bilmer Modelindeki Modüller ve Örnek Etkinlikleri

\begin{tabular}{|c|c|c|c|c|c|c|c|c|}
\hline M1 & M2 & M3 & M4 & M5 & M6 & M7 & M8 & M9 \\
\hline $\begin{array}{lr}\text { Bilim } & \text { Top- } \\
\text { lum İle- } & \\
\text { tişimi ve } & \\
\text { Önemi } & \end{array}$ & $\begin{array}{l}\text { Bilim Mer- } \\
\text { kezleri ve } \\
\text { Bilim Mer- } \\
\text { kezlerinde } \\
\text { Öğrenme }\end{array}$ & $\begin{array}{l}\text { Okul dişı } \\
\text { ortamlarda } \\
\text { öğrenme ve } \\
\text { öğretme }\end{array}$ & $\begin{array}{l}\text { Bilim nedir? } \\
\text { Bilimin } \\
\text { doğası ve } \\
\text { bilim } \\
\text { öğretimi }\end{array}$ & $\begin{array}{l}\text { Söylem } \\
\text { analizi } \\
\text { ve ileti- } \\
\text { şim be- } \\
\text { cerileri }\end{array}$ & $\begin{array}{l}\text { Bilim merkez- } \\
\text { leri modeli ve } \\
\text { deney sistem- } \\
\text { leri ve bilim } \\
\text { şovları }\end{array}$ & $\begin{array}{c}\text { Bilim } \\
\text { merkezini } \\
\text { modelle- } \\
\text { yen etkin- } \\
\text { likler ile ö } \\
\text { ders nasıl } \\
\text { yapılır? }\end{array}$ & $\begin{array}{l}\text { Bilim mer- } \\
\text { kezlerinde } \\
\text { öğrenme ve } \\
\text { öğretim uygu- } \\
\text { lamaları }\end{array}$ & $\begin{array}{c}\text { Bilim mer- } \\
\text { kezlerinde } \\
\text { öğrenme ile } \\
\text { ilgili ders } \\
\text { planı geliş- } \\
\text { tirme, uygu- } \\
\text { lama }\end{array}$ \\
\hline \multicolumn{9}{|c|}{ Öğretmenin Katıldığı Çalıştayda ilgili Modüllerden Örnek Etkinlikler } \\
\hline $\begin{array}{l}\text { Bilim merkezi } \\
\text { gezisi, }\end{array}$ & $\begin{array}{c}\text { Etkili gezi } \\
\text { planlama ve } \\
\text { Bilim ileti- } \\
\text { şimi }\end{array}$ & $\begin{array}{l}\text { Argüman- } \\
\text { tasyon, buz } \\
\text { paketi yapa- } \\
\text { lım,Topaç } \\
\text { deneyi }\end{array}$ & $\begin{array}{c}\text { Kara kutu } \\
\text { ve kara sıvı } \\
\text { etkinliği, } \\
\text { dünyanın } \\
\text { çapını he- } \\
\text { saplanması }\end{array}$ & $\begin{array}{c}\text { Kimya } \\
\text { şovları: } \\
\text { SF }_{6} \\
\text { Gaz1 }\end{array}$ & $\begin{array}{l}\text { İndikatör } \\
\text { şovları, geçiş } \\
\text { metallerinin } \\
\text { alev renkleri, } \\
\text { sihirli sıvılar }\end{array}$ & $\begin{array}{c}\text { DNA analizi } \\
\text { ve genetiği } \\
\text { değişmiş orga- } \\
\text { nizmalar (GDO) } \\
\text { tayini }\end{array}$ & $\begin{array}{c}\text { Robot } \\
\text { yapimı, } \\
\text { STEM } \\
\text { etkinlikleri }\end{array}$ & $\begin{array}{c}\text { Bilim } \\
\text { merkezini } \\
\text { müfredata } \\
\text { entegre eden } \\
\text { ders planı } \\
\text { tasarlama }\end{array}$ \\
\hline
\end{tabular}

Not: M: Modül

Mentorlük Sürecinde Öğretmenin Öğrencileriyle Yürütmek İstediği Araştırmanın Bağlamı; Okul Dışı Öğrenme: Proje Tabanlı Kimya Uygulaması Örneği

Katılımcı öğretmen çalıştaydan sonra öğrendiği yaklaşımları öğrencilerine uygulama talebinde bulunmuş, proje yürütücüsü ile iletişimde kalmıştr. Düzenli aralıklara mentorü ile görüşen Öğretmen çalıştğı okuldaki öğrenci profilini etkileyeceğini düşündüğü bir yöntem olan proje-tabanlı kimya öğretimi konusunda destek almıştr. Bu yöntem, öğrencilere ilgi ve istekleri doğrultusunda konu seçme, belirlenen konu ile ilgili yürüttükleri sistematik çalışmaları ürün olarak sonuçlandırma olanağı sağlayacağı için de tercih edilmiştir. Mentor ve öğretmen, öğrencileri gerçek hayat problemleri üzerine düşündürme üzerine stratejiler geliştirmiş; öğrencilerin yeni bilgileri problem çözme bağlamında oluşturmasını ve uygulayabilmelerini sağlamayı hedeflemiştir. Öğretmen; öğrencilerle birlikte çalışarak hedef kavramları ve kavramlar arasındaki ilişkileri oluşturma, bilimin doğası ile ilgili anlayış geliştirme, sosyal becerilerinin desteklenmesi ve öğrencilerin deneyimlerinden öğrendiklerini dikkatli bir şekilde değerlendirme yaparak rehberlik etme rolü üstlenmiştir. Özellikle laboratuar uygulamalarında öğrencilerin eleştirel düşünmesini ve bilgileri bir araya getirmesini gerektiren anlamlı sorular oluşturmalarına firsatlar yaratılmıştır.

Mentorlük sürecinde, öğrencilerin hem okullarında, hem de hastanenin mikrobiyoloji laboratuarı gibi çeşitli okul dışı ortamlarda projelerini gerçekleştirmeleri için gerekli deney malzemelerinin temini ve deneyin uygulanması sürecinde stratejilerin belirlenmesinde Öğretmene BiLMER projesinden destek verilmiştir. Ayrıca, Öğretmenin görev yaptığı okulun müdürünün de desteklemesi sayesinde, okul olarak Öğretmenin proje yürütücülüğünde TÜBiTAK 4006- Bilim Fuarları Destekleme Programına başvuruda bulunulmuş ve projeleri kabul edilmiştir. Bunun üzerine Öğretmen, kimya derslerine girdiği 10. sınıftaki öğrencilerini ders dışında bir dönem boyunca çalışarak gruplar halinde kendi gönüllü projelerini yapmaya teşvik için onlarla bir konuşma yaptığında, 4 şubeden toplam 22 öğrencinin çok hevesli olduğunu fark etmiştir. Bu grup ile bir proje sınıfi oluşturmaya karar vererek bunun için gerekli resmi düzenlemeyi yapmış ve proje sürecinde nasıl bir yol izlemeleri gerektiği konusunda mentorle görüşmüştür. Konu ile ilgili tartş̧ma ve incelemeden sonra Öğretmen, proje sınıfindaki öğrencilere normal programları dışında haftada 4 saat olmak üzere ilk 6 hafta toplu bir eğitim vermeye başlamıştı. Öğretmen, öğrencilerinin kendi istedikleri ve sevdikleri bir konuda proje çalışması yapabilmelerini istediği için, hazırlık süreci konusunda mentorüyle de konuşarak özellikle projenin yürütücü sorusunun öğrenciler tarafindan oluşturulmasını sağlayacak şekilde proje sürecini yönetmiştir. Yürütücü sorunun öğrenciler tarafindan oluşturulması proje araştırmasını öğrenci için daha anlamlı kılabilir (Kracjik, Czerniak ve Berger 2003) ve böylece 
öğrencilerin otorite anlayışı öğretmen olmaktan çıkar.

Proje Sınıfi ve 6 haftalık Proje Hazırlık Süreci: Öğretmen, proje sınıfına örnek projelerin yer aldığı videolar izletmiş ve ardından öğrencilerin projeler hakkındaki düşüncelerini ifade etmelerini sağlayarak, yapacakları proje çalışması hakkında genel bilgi vermiş ve hazırlık süreci ile ilgili kısa bilgiler paylaşmıştır.

Proje sınıfiyla yürütülen ön hazırlıktaki 6 haftalık süreç üç aşamalı planlanmıştır. "Kimya araştırma projesi hazırlamak için araştırma problemi hazırlayınız?" sorusu ile başlayan iki haftalık süreçte, her biri farklı sayıda (2-5) öğrenciden oluşan toplam 6 proje grubuna araştırma için bilgisayar ve iletişim araçlarını kullanmaları konusunda rehberlik edilerek grupların kendi proje konularını belirleyebilmeleri için araştırma yapmaları istenmiştir. Sonraki 2 hafta ise "Projenin Araştırma problemi hangi özelliklere sahip olmalıdır?" sorusu ile öğrenciler düşünme etkinliklerine dâhil edi lerek küçük grup tartşmaları ve ardından sınıfça tartışma yapılmıştır. Süreç sonunda öğrenciler birbirlerinin projelerini tartışarak değerlendirmiştir. Son iki haftada, yine her bir proje grubundan daha önce yapılmış bir kimya projesini inceleyerek sınıfa tanıtmaları istenmiştir. Projeleri inceleyen öğrencilerin, proje işlem basamakları ile ilgili çıkarımlarda bulunduğu ve az çok bir sistematik olduğuna dair şablonlar çıkardığı görülmüştür. Böylece, araştırma-inceleme aracılığıyla öğrenciler planlama, tasarlama, veri toplama, analiz etme ve daha sonra bu verilerden çıkarımlara gitme gibi süreçleri örnek projeler üzerinden tartışma firsat bulmuştur.

Proje sınıfiyla yürütülen bu ortak hazırlık sürecinden sonra, sınıftaki 6 proje grubu oldukça farklı konularda kendi projelerinin yürütücü sorularını belirlemiş ve her bir grup öğretmenlerinin rehberliğinde kendi proje çalışmalarına başlamıştır. Bu alt gruptan, Semra ve Elif kod adlı iki öğrencinin oluşturduğu proje grubu, bu makale çalışmasının konusunu oluşturmaktadır. Semra ve Elif, proje sınıfindaki çalışmalarından sonra Öğretmenleriyle 20 hafta süreyle, haftada dört saat çalışmalarını çeşitli ortamlarda sürdürerek projelerini gerçekleştirmiştir. Öğrencilerin bu projesi için, bundan sonra "öğrenci projesi" ifadesi kullanılacaktır ve söz konusu öğrenci proje süreci aşağıda verilmiştir.

\section{Öğrencilerin Proje Tabanlı Öğrenme Kapsamında Yürüttükleri Proje Süreci}

Öğrenci Projesi için Araştırma Sorusu Belirleme: Proje tabanlı öğrenme öğrencileri; hayal etmeye, tasarı geliştirmeye, plan yapmaya ve kurgulamaya sevk eden bir öğrenme yaklaşımıdır. Öğrencinin merkeze alındığı bu yaklaşımda, üründen çok öğrenme süreci önemlidir. Öğretmen, hazırlanan proje etrafinda aynı zamanda müfredatlarda bulunan çeşitli kazanımlarla ilgili öğrenmeyi de organize etmeyi hedeflediğinden sürecin başlarında öğrencilerin 10. Sınıf müfredatında yer alan üniteleri incelemelerini sağlamıştı. Ayrıca onların daha önce sundukları araştırma problemleri çerçevesinde hedef kazanımları da dikkate alacak şekilde Semra ve Elif'e projelerinin araştırma sorusunun ifadesini ve sınırlarını belirlemelerine rehberlik etmiştir. Bu süreçte Semra ve Elif, "Karışımlar" ve "Kimya Her Yerde" ünitelerindeki konularla çalışmak istedikleri için Öğretmen bu ünitelerdeki konularla (Homojen Karışımlar, Karışımların Ayrılması: Uçuculuk Farkına Dayalı Yöntemler vb) ilgili öğrencilerine sorular sorarak bu konuda yapabilecekleri projenin yürütücü sorusunu tespit etmelerine destek olmaya çalışmıştır. Bu karar sürecinde Öğretmen rehberliğinde aşağıda bazı örnekleri verilen çeşitli alt sorular sorularak beyin firtınası yaratan bir tartşma süreci yürütülmüştür.

Öğretmen: "Bu konularla ilgili yaşadığımız alanlardaki gözlemleriniz nelerdir?"

Elif: "Annem yeşil sebzeleri sirke ile ıslatiyor, marulun tadı değişiyor, fazla bekletiyor sanırım. Buna yönelik bir çözüm üretmek istiyorum...."

Semra: ".. Hasta olunca ıhlamur, nane-limon gibi bitkiler içiyoruz rahatlatiyor demek ki onların içindeki kimyasal maddeler bizi etkiliyor. O zaman bitkilerdeki kimyasal maddeleri araştirabiliriz..."

Öğretmen: "Araştırma sorusunun özellikleri nelerdir? Çalışmak istediğiniz konuları bu özellikler açısından da değerlendirir misiniz?"

Proje tabanlı öğrenme süreci, öğrencilerin değişen yaşam koşullarında kendi öğrenmelerini kurgulayarak karşılaştıkları sorunları çözebilmelerine olanak sağlayan, onların yaratıcılıklarının gelişmesine katkıda bulunan bir öğrenme yaklaşımıdır (Gillies ve Ashman, 2000; Erdem, 2002; Yurtluk, 2003; Wurdinger, Haar, Hugg ve Bezon, 2007; Filippatou ve Kaldi, 2010). Öğretmenin bu bağlamda oluşturduğu öğrenme ortamında yönlendirici ve kolaylaştııcı rolü sayesinde, 3 . Haftanın sonunda Semra ve Elif projelerinin araştırma problemini önce "Bitkilerdeki uçucu yağların bakteriler üzerine etkisi nedir?" şeklinde oluşturmuşlar ve proje sınıfına da bu konuda bir sunum yapmışlardır. Öğretmen, Mentorüyle konu üzerinde yaptıkları tartı̧̧malardan da esinlenerek, sınıfinda bu konuda öğrencilerle argümantasyon tekniği ile bir tartışma ortamı yaratmıştr. Devamında bu iki öğrenci de projelerinin araştırma sorusuna karar verirken soru ifadesinde bulunan bitkiler kelimesinin sınırlandıııması gerektiğini ve ayrıca bakteri ile ilgili yeterli bilgiye sahip olmadıklarını fark ettiklerini ifade etmişlerdir. Öğretmen "Bunlar için hangi kaynakların incelenmesi gerekir? Kimlerle görüşmeniz gerekir?" gibi yönlendirici sorular yöneltmiş bunun üzerine öğrenciler biyoloji öğretmenlerine, sağlık eğitimi alan kişilere başvurmaya karar vermişlerdir. Sınıftaki diğer öğrenci gruplarının projeleri de benzer aşamalardan geçmekte olduğundan, Öğretmen 
bu aşamada öğrencilerin bilimsel araştırmalarda farklı alanlardaki bilim insanlarının birlikte çalışarak bilimsel bilgiler üretebildiklerini fark etmelerini sağlamak için ilgili bazı belgeselleri izleterek CERN'de yapılan çalışmalardan bahsetmiştir.

Semra ve Elif, bitkilerden elde edilen yağlar konusunda bazı kaynakları da inceledikten sonra, Kekik bitkisinden Ekstraksiyon yöntemi ile elde edilecek ekstraktın hastalık yapıcı bakteriler üzerindeki etkisi konusunda proje yapmak istediklerine karar vermişlerdir. Bu konu kapsamında projenin araştırma sorusunu da "Kekik esansiyel yağlarının patojen bakteriler üzerine etkisi nedir?" şeklinde belirlemişlerdir.

Öğrenci Projesi Çalışma Takvimi: Öğrenci projeleri, süreç açısından gerçek bilimsel araştırmalara benzemenin yanı sıra öğrencilerin okullardaki diğer etkinliklerine göre daha uzun soluklu ve zaman alıcıdır. Yürütücü sorusunun belirlenmesinden sonra öğrenciler, projenin zamanını belirleyip yapılacak işlerin bu zamana göre dağıımını gerçekleştirir. Proje çalışma takviminin oluşturulması öğrencilere zamanı etkili ve doğru kullanmayı, bu bağlamda özdenetim sağlamayı da öğretir (Korkmaz ve Kaptan, 2001). Bu aşamada öğrenciler proje sürecinin en başında hazırladıkları çalışma takvimini revize ederek belirledikleri araştırma sorusuna yönelik yeniden yapılandırmışlardır.

Öğrenci Projesinde Deney, Uygulama Yapma, Veri Toplama ve Yorumlama Süreci: Bu sürecin başında, Öğretmen öğrencilerin daha önce laboratuar deneyimi olmadığını düşünerek onlara laboratuar malzemelerin tanıtmış ve laboratuar güvenliği konularında çeşitli konuları öğrenmelerini sağlamıştı. Ayrıca, öğrencilerinden projeleriyle ilgili araştırma ve uygulama sürecinde her yaptıklarını ve ilgili yorumlarını yazdıkları bir günlük tutmalarını istemiştir. Krajcik, Blumenfeld, Marx ve Soloway, (1994) tarafindan da ifade edildiği gibi, öğrencilerin kendi kendine bilgiye ulaşmasını, bilgiyi kullanmasını, ilgili alanlara bilgiyi transfer edebilmesini ve elde ettiği bilgileri uygun bir biçimde bir araya getirerek kendilerini ifade edebilmesini sağlamak amaçlamıştır. Öğretmen her hafta öğrencilerinin günlükleri incelemiş ve proje sürecinde öğrencilerin öğrenmesini gerektiği gibi yeniden yapılandırmıştır. Bu öğrenme sürecinde Öğretmen, hedeflenen konularla ilgili kavramsal değişimin sağlanması ve öğrencilerin bilimin doğası anlayışlarının geliştirilmesi yönünde projedeki çalışma bağlamını yönlendirmiştir. Ayrıca, proje sürecinde bazı konularda öğrencilere destek olabilecek insanlarla onların iletişim kurmasını ve çalışmasını sağlayacak şekilde onlara rehberlik etmiştir.

“Kekik Esansiyel Yağlarının Patojen Bakteriler Üzerine Etkisi Nedir?” başlıklı projelerinin ilk uygulama aşamasında, Semra ve Elif çalışmalarında Sokshlet Ekstraksiyon Cihazı kullanarak marketlerde paketler halinde satılan kekik ve dağ kekiğini 1:1 oranında karıştrarak elde ettikleri bitkiden uçucu yağ ekstraksiyonu yapmışlardır. Bu ekstraksiyonlarda BiLMER projesinden mentorlük desteği kapsamında sağlanan Sokshlet Ekstraksiyon Cihazını kullanmışlardır. Öğrenciler, bu cihazı tanımak ve cihazın çalışmasını öğrenmek için üniversite laboratuarına Öğretmenleriyle birlikte gelmişler ve mentorlük yapan akademisyenle de birlikte cihazla ilgili çalışmışlardır. Öğretmenin gözlemleri ve alan notları, bu birlikte çalışmanın öğrencileri çok etkilediği ve özellikle bu aşamadan sonra projeye daha hevesle sarıldıkları yönündedir. Kekik ekstraksiyonu, okulun kimya laboratuarında öğrenciler tarafindan 4 haftalık süreçte tekrarlanarak yapılmış, ekstraktlar tüplere alınarak muhafaza edilmiştir. Etil alkol ile ekstraksiyon yapan öğrenciler, süreçte saf su ile aynı işlemi yapmış ve merak ettiklerini ifade ederek iki farklı çözücünün etkisini de karşılaştırmaya karar vermişlerdir. Proje sürecinde öğrencilerin bu konulara yaklaşım hakkında fikir vermesi bakımından Ek-1 de öğrenci raporlarından alınan bir bölüm örnek olarak sunulmuştur.

Kekik ekstraktlarının patojen bakteriler üzerindeki etkileri, özel bir hastanenin mikrobiyoloji laboratuvarında disk difüzyon yöntemi ile tespit edilmiştir. Bu aşamada da öğretmen, bu tayinlerin nerelerde yapılabileceğini önce öğrencilerin araştırmasını sağlayarak bu süreci yönetmiştir. Süreçte, kekik esansiyel yağlarının patojen bakteriler üzerine etkisi ile ilgili tayinlerin yapılacağı alternatif yerlerden iki farklı hastane ve bir üniversite ile görüşmeler yapılmış ve olumsuz dönüt alınmıştr. Öğretmen bu aşamada öğrencilerine vazgeçmemek gerektiğini vurgulayarak rehberlik etmiş ve uygulama için sonunda bir hastane ile yapılan görüşmeden olumlu dönüt alınmıştr. Semra ve Elif, haftada bir gün olmak üzere 4 hafta hastanenin mikrobiyoloji laboratuarında uzman doktorlarla uygulama yapmıştır. Bu süreçte Öğretmen, öğrenciler ve mikrobiyoloji uzmanları proje konusu ile ilgili etkileşimli bir işbirliği çalışması yürüterek bir araştırma topluluğu oluşturmuşlardır. Bu vesile ile öğretmen, bilimsel bilginin gelişiminde işbirliğinin hemen her zaman söz konusu olduğuna öğrencilerin dikkatini çekerek bu konuda anlayışlarını geliştirme firsatını değerlendirmiştir. Öğrencilerin hastanede patojen bakterilerin ekimi, çoğaltılması, bakteri türlerinin ekiminin yapıldığı suşlar ve özellikleri gibi konularda çalışmaları sağlanmıştır. Daha sonra, disk difüzyon yönteminin uygulanmasını açıklayan uzmanlar, öğrencilerle birlikte üç patojen mikroorganizma suşları üzerinde kekik ektraktlarını uygulamıştır. İki hafta sonra öğrenciler kekik uçucu yağlarının patojen bakteriler üzerine etkisini bulmak için numunelerindeki zon çaplarını uzmanların desteğiyle ölçerek uygulamalarını sonlandırmıştır. Bu konuyla ilgili öğrenci raporundan alınan tablo EK- 2 de verilmiştir.

Öğrenci Projesinde Raporlama, Poster hazırlama ve Sunum: Öğrenciler, raporun içeriği ve format konusunda Öğretmenle iki hafta buluşarak üzerinde tartş̧ışlar ve kendi aralarında işbölümü yaparak raporlarını sonlandırmışlardır. 
Projenin sunumu için poster hazırlanmasında, Öğretmen sadece bazı sorular sorarak yönlendirme yapmış; fotoğraf ve içerik için seçilecek kısımları öğrencilerin kendileri tarafindan belirlenmesini sağlamıştır.

Ayrıca, öğrenciler, proje sunumlarını okuldaki TÜBITAK 4006 Bilim şenliğinde ziyaretçilerle paylaşmışlardır. Öğrencilerin projeleri için özellikle bu alanda uzman olan ziyaretçilerden olumlu değerlendirmeler almış ve çeşitli sorulara gerekçelerle açıklamalarda bulunmuşlardır. Tinker (1996) tarafindan da ifade edildiği gibi, Semra ve Elif'in de, bilim insanlarının kendi araştırmalarını diğer bilim insanları ile paylaştklarına benzer bir ortam ve deneyim yaşamalarını sağlamış ve öğretmen bu konuda da onlarla konuşarak bilimle ilgili anlayışlarını geliştirmeye çalıştı̆ını belirtmiştir. Sunum ve çalışmalarındaki başarıları nedeniyle, öğretmenin proje sınıfindaki diğer bazı projelerle birlikte Semra ve Elif 'in projesi de, Ankara, TOBB (Türkiye Odalar ve Borsalar Birliği) konferans salonunda sergilenmesi için TÜBiTAK yetkililerince düzenlenen proje sergisine davet edilmiştir. Semra ve Elif, projelerini, bu kadar geniş katılımlı bir ortam olan TOBB'deki sergide sunabildiklerine inanamadıklarını belirterek çok heyecan duyduklarını mentore de ifade etmişlerdir.

Sonuç olarak, mentorlük yapılan öğretmenin liderliğinde yürütülen proje tabanlı öğrenme kapsamında, iki öğrenci birlikte çalışarak "Kekik Esansiyel Yağlarının Patojen Bakteriler Üzerine Etkisi Nedir?” başlıklı özgün bir uygulamalı kimya projesi geliştirmiştir. Yukarıda açıklanan bu öğrenci projesinin işlem basamakları Tablo 2 de özetlenerek verilmiştir.

\section{Tablo 2: Proje Tabanlı Kimya Öğretimi İşlem Süreci}

Proje Tabanlı Öğrenme Uygulaması- Öğrenci Projesinin İşlem Basamakları

Ön Hazırlık

Planlama

Projenin Amaç/Konusunun Belirlenmesi

Veri Toplama/Uygulama

Rapor ve Poster Hazırlama

Projenin Sunumu

\section{Uygulamaların İçeriği}

Proje nasıl hazırlanır?

Proje çalışmalarının planlanması

Örnek projelerin ve bilimsel çalışmaların incelenmesi

1.Kekik ekstraksiyonu

2-Kekik esansiyel yağlarının patojen bakteriler üzerine etkisinin belirlenmesi

Verilerin yorumlanması ve rapor yazımı

Poster için kullanılacak resim/foto seçilmesi ve poster tasarımının yapılması

Proje sürecinin ve sonuçların paylaşılması
Uygulamanın Gerçekleştirildiği Mekânlar

\section{Okul}

Okul/Ev

Gazi Üniversitesi Kütüphanesi, Milli Kütüphane ve Öğretmen rehberliğinde internet araştırması

Okul Kimya Laboratuarı

Hastane Uygulaması: Mikrobiyoloji Laboratuarı

Okul/ Ev
1.Okul Bahçesi

2.TOBB Konferans Salonu

\section{Veri toplama Araçları}

Bir örnek olay incelemesi olan bu araştrrmada makalenin birinci yazarı tarafindan öğretmenle, yürüttüğü proje tabanlı öğrenme proje sürecini önce açık yönlendirmesiz şekilde anlatmasının sağlandığı bir görüşme yapılmış ve kayıt altına alınmıştır. Sonra araştırmacı tarafindan bu kayıt incelenerek öğretmenin görüşleri, deneyimleri ve değerlendirmeleri ile ilgili veri toplama amaçlı yarı-yapılandırılmış bir görüşme daha yapılmıştı. Çalışmada, mentorün ve öğretmenin süreçteki alan notları da yine verilerin desteklenmesi sürecinde değerlendirilmiştir. Ayrıca öğrencilerin 20 haftalık proje uygulama sürecinin başında, ortasında (11. Haftada) ve sonunda bu makaledeki araştırma amacına yönelik öğrencilerle yapılan yarı yapılandırılmış görüşmeler de veri kaynağı olarak çalışmada kullanılmıştr.

Öğretmen öğrencilerin, proje araştırma sorusunu oluşturdukları andan itibaren günlük tutmalarını sağlamış ve bu günlükleri haftalık olarak inceleyip tespit ettiği bazı konuları mentore de danışarak proje sürecinin gerektiği şekilde revize edilmesi sağlanmıştır. Dolayısıyla bu öğrenci günlükleri de bazı veriler için kaynak teşkil etmiştir. Öğretmen tarafindan öğrencilerin deneyleri tasarlama sürecinde ve laboratuvar uygulamaları aşamasında gözlem notları yanında büyük ölçüde video kaydı alınması da sağlanmıştr. Proje sürecinde, öğretmen öğrencileriyle birlikte zaman zaman bu 
kayıtları izleyerek konular üzerinde birlikte tartışmalar yapmışlardır. Bu kayıtlar, aynı zamanda bu araştırmada da veri kaynağı olarak değerlendirilmiştir.

\title{
Veri Analizi
}

Bu araştırmada incelenen örnek olay araştırması için çeşitli araçlarla nitel veriler toplanmıştr. Cresswell (1994), örnek olay incelemesini doğal ortamında yürütülen, katılımcıların detaylı görüşlerinin aktarıldığı, sözel verilerden oluşturulan, bütüncül ve karmaşık bir çerçeve içerisinde, sorgulamaların olduğu bir süreç olarak tanımlamaktadır. Veriler değerlendirilirken, gözlem, görüşme ve günlüklerden elde edilen anlatımlar öncelikle transkript edilmiş, daha sonra bu ifadelerden kod ve kategorileri oluşturulmuştur. Öğretmenin öğrenciler ile ilgili gözlemleri, öğrencilerin tuttukları günlükler ve Öğretmenin mentoründen destek aldığı konular kodların ve kategorilerin oluşturulmasında etkili olmuştur. Örneğin Öğretmen bilimin doğası konusunda farkındalığı yüksek olan biri olduğu için öğrenciler ile ilgili aldığı notlarda özellikle bu konularda vurguları olmuştur. Bu vurgular da bilimin doğası ile ilgili bir tema oluşmasını sağlamıştı. Elde edilen kodlardan da temalar ortaya çıkarılmıştır.

\section{Bulgular}

Elde edilen nitel veriler analiz edilerek toplu olarak incelendiğinde, öğretmenin iki öğrencisiyle birlikte gerçekleştirdikleri bilimle ilgili konularda proje tabanlı öğrenme ve uygulama sürecinin öğrencilere sağladığı kazanımların beş temel tema altında toplanması uygun görülmüştür: Bu temalar; kavramsal, duyuşsal, bilimin doğası ile ilgili anlayışlar, disiplinler arası ilişki ve çevreye duyarlılıktır. ilgili temaları besleyecek veriler, çeşitli veri toplama araçlarından harmanlanarak alınmıştır. Bu veriler bazen öğrencilerin ham görüşlerini, bazen öğretmenin konu ile ilgili veriye dayalı gözlemlerini, bazen de öğrencilerdeki değişimi kapsamaktadır. Çalışmada elde edilen nitel veriler, Neuman'ın (2006) tarif ettiği üzere birincil yorumlar ve yorumlardan çıkarımlar olan ikincil yorumlar şeklinde yorumlanarak aşağıda verilmiştir. Üçüncül düzey yorumlar yani sonuçların literatür/kuramlar ile karşılaştrılması hem bu bölümde hem de tartş̧ma bölümünde ele alınmıştr.

\section{Öğrenci Kazanımları}

1-Kavramsal/ Bilişsel; Öğretmenin alan notlarından öğrencilerin okul dışında proje tabanlı uygulama sürecinde; kavramları öğrenme konusunda sorumluluk aldıkları, kavramsal değişim süreci yaşayarak anlamlı öğrenmeye ulaştkları gözlenmiştir. Var olan yanlış kavramalarını öğrencilerin süreç içerinde kendilerinin tespit edebildiğini gösteren bulgular vardır. Proje tabanlı öğrenme sürecinde, öğrencilerde çeşitli kavramlarla ilgili anlamlı öğrenme gerçekleştiğini şu bulgulara dayanarak söyleyebiliriz. Öğrenci günlük kayıtlarında, Elif isimli öğrencinin şu ifadeleri yazdığı görülmüştür:

\begin{abstract}
"Kitaptan okuduğumda kaynama ve buharlaşmanın farklı kavramlar olduğunu hiç anlayamamıştım ama deney yaparken fark ettim ki aslında çok kolaymış. Ekstraksiyon yaparken kaynama başlamasa da soğuk suyu sürekli çalıştrıyorduk. Öğretmenimiz bunun nedenini sordu, düşünmeye başladım. Bunu düşünmemizi ve ertesi gün yazarak tartışmamızı istedi. Ardından bize bir etkinlik kâğıdı dağıtt, yönergeleri Semra ile sırayla uyguladık: Dereceli silindire 2 cc etil alkol alarak masaya döktük, masadaki etil alkolün miktarını/ boyutunu gösteren bir renkli kâğıdı ölçüt olacak şekilde masaya bantladık. Masadaki etil alkolün miktarı ve zamanla ilgili gözlemlerimizi not ettik. Zamanla etil alkolün azaldığını gözledik. Etkinlik kâğıdındaki soruları Semra ile tartş̧tk. Etkinlikle buharlaşmanın her sıcaklıkta olabileceğini fark ettim. Bir beherde etil alkolün kaynama noktasını yaklaşık olarak ölçtük. Gözlemlerimizi not ettik. Buharlaşma ve Kaynama kavramlarının farklı olduğunu anladım. Ertesi gün Semra ile rapora ....soğuk suyu açıyoruz çünkü etil alkolle hazırladığımız çözücü kaynamadan da buharlaşıyor, madde kaybını en aza indirmemiz gerekiyor .... Şeklinde yazdık"
\end{abstract}

Ayrıca, aynı öğrenciyle yapılan görüşme kayıtlarından alınan bu konu ile ilgili bir cümlesi de şu şekildedir:

"Buharlaşma dendiğinde sadece kaynama anında olduğunu hayal ediyordum, oysa şimdi değişti. Kaynama ile buharlaşmanın farklı olduğunu o kadar iyi anladım ki arkadaşlarıma sınav öncesi konuyu ben anlattım."

Öğretmenin proje süreciyle ilgili notları değerlendirildiğinde, notlarında, kekik ekstraksiyonunun ilk haftasında öğretmenin karışım/saf madde/bileşik ve buharlaşma/ kaynama gibi kavramlarla ilgili sorularına Semra ve Elif'in cevap vermekte zorlandığını, beş sorunun üçünü hiç cevaplamadıklarını, iki soruya ise tek kelimelik cevaplar verdiklerini yazmıştr. Daha sonra ise, 6 haftalık süreçte her hafta farklı kavramlarla ilgili sorulan soru sayısı artmasına rağmen cevaplama oranlarının \%70 lerde olduğu süreç sonunda sorulara \%90 oranında cevap verdiklerini not etmiştir. Notlara göre, öğrencilerin sorulara verdiği cevaplardan bir örnek şöyledir: Öğretmenin "Neden ikinci çözücü olarak saf su kullanmak istediniz?" sorusuna Semra çözünme kavramını açıklayarak başlamıştı. Taneciklerin moleküler yapısı ile ilgili yaptıkları araştrrmayı göstermek için dosyasındaki bilgileri göstererek etil alkol ile saf suyun her ikisinin de polar taneciklerden

| Kastamonu Eğitim Dergisi, 27(5), 2019| 
oluştuğunu açıklamıştır. Elif de bu konudaki düşüncelerini:

"Etil alkolün çözücü olarak kullanıldığı bir deneyde saf su da çözücü olabilir ama acaba elde edilen miktar ve etki süreci aynı olacak mı, merak ediyoruz"

Şeklinde ifade etmiştir. Öğretmen, yine bu konuyla ilgili olarak, ekstraksiyonun 4. Haftasında öğrencilerin sorulara cevap verirken verileri kullandıklarını, gerekçelerle düşüncelerini desteklemeye başladıklarını not etmiştir.

Ayrıca, projeyi gerçekleştiren öğrencilerin öğrendikleri kavramları günlük hayatla ilişkilendirebildikleri, olayların nedenlerini gerekçelerle sunarak aynı bilginin farkı alanlarda kullanılabilmeyi öğrendikleri sonucunu çıkarılabilir. Şöyle ki, çözünme ve çözünmenin moleküler boyutunun anlatılmasından yaklaşık on gün sonra, Elif ve Semra heyecanla Öğretmenin yanına gelerek konuyu farklı bir alanda kullandıklarını aşağıdaki ifadeyle dile getirmiştir. Elif'in bu ifadeleri, bilimsel kavramlarını günlük hayatta kullanabilmesinin yanında bilim insanı gibi düşünme heyecanını kazanmaya başladığına da işaret etmektedir.

Elif'in cümleleri:

"Oje sürerken su ile ojeyi çıkaramadığımı düşündüm. Suyun polar yapıda olduğunu düşündüm. O zaman oje apolar olmalı dedim ama hocam tabii ki hipotezimi araştırdım. Ojenin yapısının apolar olduğunu öğrendim, daksilin de apolar olduğunu düşündüm. Sevdiğim oje renkleri ile daksili karışttrdım. Renkli daksiller yaptım. Ben renkli daksil olsun istiyordum ama kırtasiyelerde yoktu. Homojen renkli daksilim oldu. Yaptiğım hataları silerken kullandığım renkli kalemlere uygun daksili kullanabilirim. Hayatımdaki her şeyi sürekli bu şekilde düşünmeye başladım."

Nitekim Demirel (2005), proje tabanlı öğrenme süreci sonunda öğrencilerin örneklerle kanıtladıkları karmaşık, entelektüel, mantıklı ürünler oluşturduğunu; ortaya koydukları ürünlerini kendilerinin değerlendirdiğini söyler. Benzer şekilde Kaşarcı (2013), proje tabanlı öğretimde öğrencilerin bilgilerini gerçek dünya olaylarının içerisine yerleştirebildiğini ve bilgilerini benzeri ortamlara transfer ettiklerini belirtir. Proje tabanlı öğretimi yürüten Öğretmen, öğrencilerinden proje süresince farklı gruplara projelerinin tüm aşamalarını, nedenleri ile açıklayacak şekilde sunmalarını istemiş, bu sürecin de öğrencilerin eleştirel düşünme ve sorgulama becerilerini gelişmesine katkı sağladığını ifade etmiştir. Benzer şekilde, Herron, Magomo ve Gossard (2008) tarafindan yapılan çalışmada da, öğrencilerin proje deneyimlerinden yola çıkarak çeşitli bilgilerini farklı alanlarda uygulama deneyimi kazandıkları belirtilmektedir.

Öğretmenin gözlem notlarına göre; süreç öğrencilerin kaynak araştrrma, projede kullanabileceği bulguları tespit etme ve hedefi açıklayan bir ürün oluşturma yeteneği kazanmaları konusunda da etkili olduğunu göstermektedir. Öğretmenin bu görüşünü destekleyen bir husus öğrenci günlükleri incelenirken tespit edilmiştir. Öğrenci günlüğüne göre, proje sürecinde kimya dersinde asit-baz kavramlarıyla tanışan Semra, ödev olmadığı halde öğrendiği "indikatör" kavramını araştırmış; doğal indikatör yapmaya karar vermiş ve evindeki malzemelerle deneyler yapmıştır. Kırmızılahana, ıspanak, çay gibi ürünleri kullanan Semra, bulgularını raporlayarak Öğretmenine ve sınıfa sunmuştur. İndikatör olarak renk değiştirmeyen grupların nedenlerini de araştırmıştr. Demirel (2005) proje tabanlı öğrenmenin öğretmen merkezli sınıf uygulamalarının yerine; kalıcı ve gerçek dünya konu ve uygulamalarıyla ilgili öğrenme aktivitelerini geliştirdiğini belirtmektedir. Bu çalışmada da, öğrencilerin bu yönde uygulamalara ilgisinin arttğı tespit edilmiştir.

2. Duyuşsal: Verilerin analizinden ortaya çıkan bir diğer tema, duyuşsal etkilerle ilgilidir. Okul dışı ortamlarda yürütülen proje tabanlı kimya öğretim sürecinde, öğrencilerin kimyaya ve bilime karşı tutumlarının ve ilgisinin olumlu yönde geliştiği, gerek Öğretmenin notlarından gerekse öğrenci görüşmelerinden tespit edilmiştir. Öğrencilerin derse daha aktif katıldıkları, bu bağlamda uygulamalara ve deneylere öncesine göre daha istekli oldukları, derse ilgilerinin arttğı Öğretmenin gözlem notlarında sık sık tekrarlanmaktadır. Ayrıca süreç ile ilgili öğrenci görüşleri incelendiğinde, öğrencilerin laboratuardaki uygulamaları çok eğlenceli buldukları, hastanedeki uygulamalardan çok heyecan ve memnuniyet duydukları ortaya çıkmıştır. Öğrencilerle yapılan görüşmelerden alınan aşağıdaki örnek ifadeler bu sonuçları destekler niteliktedir.

\section{Semra:}

"10 yıldır sınıfta öğreniyorduk, ilk defa laboratuarda, hastanede, kütüphanede farklı ortamlarda öğrenmekle ilgili bir proje yaptık. Bu sırada öğrenmeye çalışmaktan çok farklıydı. Sınıfta ders anlatılırken hayal de kurduğum zamanlar olmuştur, uykum geliyordu zaman zaman, anlamadığımda soramıyordum. Oysa burada bambaşka oldu, öğrenmek için içimden gelen bir istek var ve öğrendiğimi hissettiğimde mutlu oluyorum".

Elif ise;

"Hastanenin mikrobiyoloji laboratuarında olmak harikaydı. Kendimi çok önemli hissettim. Sadece okulun 
en çalışkan öğrencilerinin alındığı bir çalışma değildi, ben de başarabiliyordum. Bilmediğim kavramları gitmeden önce araştırmak istiyordum. IIlk defa zorunlu olmadığım halde öğrenmek için ders çalıştım. Hafta gelse de gitsek diye heyecanlanıyordum..."

Semra ve Elif birlikte:

"Projeyi anlatmak çok güzel bir duygu. Biz yaptık diyoruz ve her gelene anlatmak için herkesi masaya çağırıyoruz. Bizim başardığımız bir ürünümüz var. Kendimize güvenerek anlatiyoruz. Kavramları bilmek, soranlara açıklamak, doğru bir çalışma yaptığımızı onların yüzlerinde görmek çok güzel bir duygu. Üniversiteden gelen misafirlere, okuldaki öğretmenlerimize anlatiyoruz ve dersimize giren bazı öğretmenler inanılmaz şaşırıyorlar. Bunu görmek eğlenceli... Arthk doğru şekilde çalışmayla nelerin başarılabileceğini gördük."

Semra:

"Öğretmenimiz ilk derste kimya hayattır demişti. Bu projede olmakla artk ben de kimyanın yaşamın her yerinde olduğuna inanıyorum. Kimya dersini çok seviyorum. Öğretmenimizin ne demek istediğini sanırım yeni anladım."

Elif:

"Öncesinde karar veremiyordum ama projeden sonra artı eminim alan tercihimde MF alanını seçeceğim."

Öğretmen görüşleri, öğrenci görüşleri ve öğrencilerin günlüklerinin analizinden duyuşsal boyutla ilgili bulunan sonuçlar birbirini destekler niteliktedir. Örneğin, Öğretmenle yapılan görüşmede, Öğretmenin;

“..bu proje tabanlı uygulama öğrencilerin okula isteyerek ve severek gelmelerine katkı sağladı. Öğrencilerin uygulama yapılmadan önceki yıla ait devamsızlık durumlarını uygulama yapılan dönemdeki devamsızlık durumları ile karşılaştırdım, uygulama yapılan dönemde iki öğrencinin de hiç devamsızlık yapmadıklarını gözledim"

Şeklinde bir ifadesi vardır. Bu konu ile ilgili olarak öğrencilerden Semra'nın günlüğüne yazdığı bir bir not da oldukça dikkat çekicidir:

"...raporlu olduğum halde deneyi tamamlamak için okula gelmeyi çok istiyordum ve bunun için ailemi zorla ikna ettim"

Okul dışı öğrenme ortamlarının öğrencilerin duyuşsal özelliklerini olumlu yönde etkilediğine dair Şentürk ve Özdemir (2014) de benzer sonuçlar elde etmiştir. Okul dışı öğrenme ortamında öğrencilerin bilime yönelik tutumlarını artırdıklarını raporlamışlardır. Ayrıca bu bulgular, öğretmenlerin bilime yönelik tutumlarının ya da öğretmeye yönelik inançlarının öğrencilerin öğrenme ve tutumlarına etki ettiği (Kirikkay, 2009; Miranda, 2012) sonucunu da desteklemektedir.

3.Bilimsel Araştırma ve Bilimin Doğası ile ilgili Anlayışlar; Veri analizleri doğrultusunda ortaya çıkan bir başka tema da, öğrencilerin okul dışında proje tabanlı kimya uygulaması sayesinde bilimin doğası ve bilimsel araştırmalarla ilgilidir. Görüşmelerde öğrenciler, bu proje sürecinde bilimsel bilgiye nasıl ulaşıldığını deneyimleyerek öğrendiklerini vurgularken; Öğretmen de katıldığı BiLMER çalıştayında bilimin doğası ile ilgili uygulamalı etkinliklerin ilgisini çok çektiğini ve bu konuları çok sevdiğini belirtmiştir. Ayrıca mentorle de görüşmeleri sonunda, bu proje sürecinde öğrenciler araştırmalarını yaparken her firsatı onların bilimle ilgili anlayışlarını geliştirmek için değerlendirmeye karar verdiğini ifade etmiştir. Nitekim diğer bulgular da, öğrencilerin bilimsel araştırma ve bilimin doğası ile ilgili anlayışlarında önemli kazanımlar edindiğini destekler niteliktedir: Örneğin Elif ve Semra'nın aşağıda verilen ifadeleri, öğrencilerin proje sürecinde yeni sorular ya da problemlerle uğraşırken "bilim" ve "bilim insanları" ile ilgili anlayışlarının ve aynı zamanda sorgulama becerilerinin de geliştiğini göstermektedir.

Elif:

"Bilim dendiğinde sadece çok zeki olanların uğraşacağı, en çalışkanların bununla ilgili fikir yürüteceği bir şey düşünüyordum. Özel yetenekleri olanlar ve zeki olanlar bilimle uğraşır diye inanıyordum. Oysa projede hedeflediğimiz ve çözmek istediğimiz problemle ilgili bilimsel bir çalışma yürüttük. Demek ki bilim de ilgilenebileceğimiz bir alan. Belirli bir program dâhilinde çalışarak biz de bilimsel bir çalışma yürütüyoruz. Öğretmenimizin anlattı̆ı bilim insanları örnekleri, araştırmalarımızda okuduklarımız, hastanedeki doktor ablanın hikâyeleri hepsi özel bir yeteneğe sahip olmak gerekmediğini gösterdi bana"

Semra:

"Daha önce hiçbir derste bu şekilde aktif olmamıştım. Öncesinde konuşmaya bile çekinirken, hazırlık esnasında Elif ile sürekli birbirimize sorular soruyorduk. Yaptığımız her aşamayı en ince detayına kadar açıklamamı gerekiyordu. Bizim fark etmediğimiz veya unuttuğumuz bir aşama olursa zaten öğretmenimiz mutlaka soruyordu. ilk başlarda sorulara cevap verirken hata yapmaktan çok korkuyordum ama ilerledikçe hatalarımı düzeltebileceğimi ve ilerlememi bu şekilde fark edebildiğimi gördüm. Öğretmenimiz bazı hatala- 
rın bilimde ilerleme sağladığını anlattğında çok şaşırmıştım. Zaman geçtikçe herkese projeyi anlatayım da eksiklerimi göreyim diye düşünmeye başladım. Hatta bana anlatılanlarla ilgili sürekli soru sorduğumu fark ettim: Neden, gerekçesi ne, nasıl?..gibi. Sözleri hemen kabul etmem zorlaşt sanırım. Sonuç olarak projede olmak farklı düşünmemi ve duyduklarımı sorgulayabilmemi sağladı."

Elif ve Semra, projelerini gerçekleştirirken bilim insanlarının özelliklerini fark etmenin yanında bilimsel bilgiye ulaşmanın tek bir yolu ve yöntemi olmadığını da yaşayarak öğrenmişlerdir. Projeye başlamadan önce öğrenciler nasıl bir metot kullanacaklarını ve araştırma sonunda hangi cevaplara ulaşacaklarını bilmeden yola çıkmıştır. Yani öğrenciler araştırma-inceleme yaparken işlem adımları önceden belirlenmiş geleneksel laboratuar çalışmalarından (Krajcik vd., 1994) daha farklı olarak gerçek bilimdekine benzer açık uçlu bir araştırma süreci yaşamışlardır. Öğrenciler için süreçte, gerçek bilimdekine benzer şekilde yanlış başlangıçlar, çözülmesi gereken sorunlar, çıkmaz sokaklar gibi durumlarla karşılaşmışlardır. Öğretmenin notlarından alınan aşağıdaki anlatım yaşanan bu durumlara örnek olarak verilmiştir:

"Kekik yağının eldesi için uğraşırken öğrenciler steril olarak nasıl saklayacakları konusunda endişe etmeye başladılar. "Miktar çok az ve madde kaybı olursa ne yapacağı??" şeklinde endişelerini dile getiriyorlardı. Sonunda sağlık ocaklarında kan alınırken kullanılan ağzı lastik tüplerin olabileceğini Elif önerdi. Öğretmen sağlık ocağından tüpleri temin edilmesine aracılık etti, Ekstraktın nasıl tüplere konulacağını soran Öğretmene Semra'nın önerisiyle, büyük boy şırınga ile elde ettikleri kekik yağlarını her defasında çekerek tüplere enjekte ettiler. Böylece laboratuarda başka maddelerin karışmasını ve madde kaybını önlediler. 08.04.2016

Öğretmen, öğrencileriyle yaşadıkları bu olaydan hemen sonra, kendi deneyimlerini de örnek göstererek bilimsel araştırmaların adım adım takip edilen bir prosedürü olmadığı konusunda onlarla açık düşündürücü yaklaşımla bir tartışma ortamı yaratarak bilimin doğasının bu boyutları ile ilgili anlayışlarını geliştirmeye çalıştı̆ını ifade etmiştir. Öğrencilerle yapılan görüşmelerde ve Semra'nın aşağıda verilen cümlesi, öğrencilerin bilimsel yöntemle ilgili anlayışlarının geliştiğini desteklemektedir.

\section{Semra:}

"Projemizde birden fazla yöntemle sonuca ulaşılabileceğini öğrendim. Bir tane yöntem var deyip vazgeçmemek gerek. Patojen bakterilere uygulama yapmak için birçok yol denedik ve vazgeçmeden başardık. Başarmak için vazgeçmeden mücadele etmeliyiz."

Ayrıca çalışmada verilerin analizinden, öğrencilerin proje sürecinde bilimin doğasına yönelik gözlem ve çıkarım arasında fark olduğunu ve ayrıca deneyde gördükleri sonuçları yorumlarken kişisel özelliklerin ve hayal gücünün etkin olduğunu deneyimleyerek fark etmiş oldukları bulunmuştur. Öğrencilerin proje sürecinde hem Öğretmenle sık sık yaptıkları tartı̧malar ve hem de sosyal etkileşimde bulundukları diğer alan uzmanları ile sorgulayııı süreç içinde yer almış olmaları, onların bilimsel süreçlerle ilgili farkındalıklarını arttırmıştır. Elif'in bu bağlamdaki bir söylemi aşağıdaki gibidir:

"Bilimsel süreçler izlenerek istenen sonuçlar ölçülerek bulunur diye düşünüyordum. Oysa deneylerden elde ettiğimiz sonuçların aslında ne anlama geldiğini yorumlamak için bir bağ kurmak gerektiğini fark ettim. Mesela, zon çapları ile ilgili doktor ablanın sorusunda Semra ile farklı yorumlar yaptik başta, sonra birbirimizi ikna etmeye çalıştk, etken maddenin etkisi üzerine yaptığımız tartı̧̧mada bilgimizden bir sonuç çıkarmamız ve yorum yapmamız gerekiyordu. Demek ki deney bize her şeyi söylemiyordu. Bağlantıyı biz bulmalıydık, ikimiz farklı yorumlamıştk."

Öğretmeninin saha notlarına dayanarak, Semra ve Elif 'in işbirliği içinde çalıştı̆̆ı ancak bazı durumlarda farklı yorumlarının olduğu ortaya çıkmıştır. Öğretmen bu durumu yaratıcılık, hayal güçleri ve düşünme alışkanlıkları ile ilgili bireysel farklııklar ile açıklamıştı. Dolayısıyla Öğretmen bu bireysel farkıııkları tespit edip bilim insanlarının bilim yaparken sadece mantıksal çıkarımlar değil aynı zamanda hayal gücü ve yaratıcılıklarını da kullandıkları ve düşünme alışkanlıklarının nasıl olduğu ile ilgili öğrencilerle tartı̧ma ortamı yaratmıştı. Örneğin, zon çaplarının büyük olması ile kekik ekstraktının etkinliği arasında nasıl bir ilişki olduğunu soran asistan doktora iki öğrenci farklı ve zıt cevaplar vermiştir. Öğretmen "Bilim insanları da sizin gibi aynı verileri farklı yorumlayabilirler? Sizce bunun nedeni nedir?” sorusu ile tartş̧mayı başlatmıştır.

Elif:

"Bilimsel süreçler izlenerek istenen sonuca ulaşılır diye düşünüyordum. Oysa deneylerden elde ettiğimiz sonuçların aslında ne anlama geldiğini yorumlamak için bir bağ kurmak gerektiğini fark ettim. Mesela, zon çapları ile ilgili doktor ablanın sorusunda Semra ile farklı yorumlar yapttk başta sonra birbirimizi ikna etmeye çalıştık, etken maddenin etkisi üzerine yaptı̆̆ımız tartışmada bilgimizden bir sonuç çıkarmamız ve yorum yapmamız gerekiyordu. Demek ki deney bize her şeyi söylemiyordu. Bağlantıyı biz bulmalıydık ikimiz farklı yorumlamıştik."

Saha notlarından alınan öğrencilerin bu ifadelerine dayanarak Öğretmenin, bilimsel araştırmalarda gözlem ve çıkarım, gözlemlerin teori yüklülüğü gibi bilimin doğası ile ilgili boyutları açık düşündürücü yaklaşım kullanarak öğrencileriy- 
le tartışabildiğini söyleyebiliriz. Aynı şekilde veriler, öğrencilerin bilimsel bilginin değişebileceğine ilişkin anlayışlarında da gelişme olduğunu ortaya koymaktadır. Bu konuda Semra'nın söylemi örnek olarak aşağıda verilmiştir:

"Bilimsel bilgilerin zamanla değiştiğini öğrendim. Elde edilen verilerle, yeni bulgularla ulaşılan sonuçlar değişebiliyor. Önceden bilim adına konuşuyorum diyenleri dinlediğimde söylediklerinin hiç değişmeyeceğini düşünürdüm oysa şimdi yeni bulgularla değişebileceğinin farkındayım."

Bunlara ilaveten, Öğretmen öğrencilerinin bilim insanlarının zihinsel alışkanlıklarına benzer alışkanlıklar edinmeye başladıklarını not etmiştir. Bunu Semra isimli öğrenciyle yapılan mülakat notlarından alınan birincil düzey veri ile somutlaştırmak gerekirse;

"Deney sonrasında neden etil alkol ve saf kekik yağı, saf su ile ekstrakte edilen kekik yağından daha etkin diye düşünmeye başladım. Kendi içimde nedenleri tartıştı̆ımı fark ettim, veriler üzerinde gerekçelerle düşünmeyi öğrendim sanırım."

Bu konuda Elif ise şu şeklide konuşmuştur:

"Projenin başında önce projeyi merak etmiştik, yaşadıklarımızdan başlayarak sorgulamayı öğrendik, merak ettiğimiz alanları belirledik, bunu yaparken çevremize baktık, problemler belirledik, araştırmalar yaptık, çaıışacağımız konuyu sınırlandırdık. Birçok aşamayı yavaş yavaş uyguladık. Laboratuvar deneyimlerimiz çok yorucuydu ama vazgeçmemeyi öğrendik. Tüm yaşadıklarımızdan sonra bilim insanları ile ilgili yaşanmışıkları öğrendiğimde gözlerim doldu. Biz de benzer bir süreçten geçmişiz. Bilimle uğraştık diye düşündüm ve inanamadım".

Ayrıca öğrenciler Elif ve Semra, araştırma yaparken önceden planlanmayan bir soruyu da uygun ortam geliştiği bir anda merak edip etkisini araştırmışlardır. Öğretmenin yönlendirmeleri ile bilim insanlarının da benzeri süreçlerden geçtikleri konusunda deneyimleyerek farkındalık geliştirmişlerdir. Öğrencilerin araştırma sürecinde farklı çözücülerin etkisini de karşılaştırmaya karar vermeleri bu duruma somut örnek sunmaktadır.

4. Disiplinler Arası ilişki; Nitel veri analizinden ortaya çıkan bir diğer temadır. Öğrenciler, okul dışı proje tabanlı kimya uygulaması sürecinde farklı disiplinlerle ilgili kavramları araştırarak açıklamalarında bunları bir arada kullanmışlardır. Gerçek hayattaki problemlerin çözümünde sınırları keskin çizilmiş tek bir alan olmadığını; kimya-biyoloji-matematik gibi farklı adlandırılan disiplinlerin bütünleştirilerek bilişsel düzeyde ilişkilendirilmesi gerektiğini fark etmişlerdir. Uygulamanın ilk haftalarında, destek almaları gereken kavramların kimya ile ilişkili olup olmadığı noktasında tereddüt yaşayan öğrenciler süreç ilerledikçe bakteri gibi kavramların hangi alanlarla (Biyoloji, matematik vb) ilişkili olduğunu tartşmaya ve intiyaç duydukları desteği ilgili öğretmenlerden talep ederek o alanlardaki ilgili kavramları ve becerileri öğrenmeye başlamışlardır. Bu durum ile ilgili Elif'in bir cümlesi şu şekildedir;

"Kekik türlerini araştırırken Biyoloji'den yararlandık, kekik esansiyel yağının moleküler yapısı Kimya ile ilgili. Mezurla etil alkolün miktarını ölçtük, tartının darasını aldık, hesap yaptık matematik kullandık. Birçok dersi bir deneyde birleştirdik gibi geliyor."

5. Çevreye Duyarlılık; Öğrenci görüş ve öğretmen görüşlerinin analiz edilmesinden ortaya çıkan son temadır. Okul dışı proje tabanlı kimya uygulaması sürecinde, öğrencilerin çevre duyarlııklarında da gelişmeler gözlenmiştir. Kimyasal attkların çevreye verdiği zararlar konusunda araştırmalar yapan öğrenciler, haberlerde ve dünyadaki mevcut durumla ilgili fikirlerini paylaşmaya başlamışlardır. Aile ve çevrelerine sorular hazırlayarak deterjan kullanım oranlarını belirlemeye çalışmışlardır. Bu konuda Semra;

"Fark ettim ki annem çok fazla deterjan ve çamaşır suyu kullanıyor. Artık sürekli annemi uyarmaya başladım. Çevreye olan zararla ilgili öğrendiklerimi sürekli anlattyorum evde. Temizlik ürünlerini düşünüp, aynı temizliği yapacak ama doğaya zararlı olmayan maddeler var mı diye düşünüyorum"

Görüşmelerde de, Öğretmen öğrencilerin proje sürecinde çevre ile ilgili bilgi, duyarlıık ve davranışlarında olumlu yönde gelişme olduğunu dile getirmiştir. Öğretmen, proje sürecinde öğrencilerin çeşitli yönden kazanımları olduğunu ve proje sonrasında öğrencilerin hallerinin değiştiğini vurgulayarak hem Elif, hem de Semra'da bilim insanı olma hevesleri oluştuğunu gözlediğini, üniversitede okumak istedikleri bölümün dahi bu süreçten etkilendiğini ifade etmiştir. Hatta proje tamamlandıktan belirli bir süre sonra, öğrencilerin bu hedeflerine ulaşabilmek için Semra'nın okuduğu alanı MF olarak değiştirdiğini, hatta Elif'in de daha iyi fen öğrenmek amacıyla okul değiştirdiğini ifade etmiştir.

\section{Öğretmen-Mentor Etkileşimi; Öğretmen Kazanımları}

Öğrencilerin yukarıda bahsedilen kazanımlara ulaşmasında öğretmenin mentoründen aldığı destek kendi ifadesine göre yadsınamayacak boyuttadır. Baki ve Bütüner (2009) un açıkladığı gibi, proje-tabanlı öğretim sürecinin en önemli sorunlarından biri öğretmenlerin öğrencilerine rehberlik etmede sorun yaşamasıdır. Ayrıca, Saban (2002) ye göre proje

| Kastamonu Eğitim Dergisi, 27(5), 2019| 
tabanlı öğrenme yaklaşımının uygulanmasını zorlaştıracak başka durumlar da söz konusudur. Mesela, öğrencinin ilgisini çekecek etkili projeler tasarlamak ve projenin her evresini kontrol etmek öğretmenlere zor gelmektedir. Katılımcı Öğretmen bu gibi sorunları aldığı mentorlük desteği sayesinde rahatça aşth̆̆ını ve hem de bu sayede öğrencilerin istediği konuda proje yapmalarını sağlayabildiği için çok memnun olduğunu ifade etmiştir. Proje tabanlı öğrenme uygulamaları genellikle çok zaman aldığından ve proje sürecinde ortaya çıkan problemlerle öğretmen ve öğrencinin başedememesi gibi nedenlerden dolayı sadece öğrencilerin değil öğretmenin de projeyi sürdürme isteklerinde azalma görülebilmektedir (Grant, 2002; Saban, 2002). Ancak, bu konuda profesyonel mentorlük desteği alan öğretmenin bu süreçte öğrencileriyle böyle bir durum yaşamadığı ve aksine öğrencileriyle verimli ve zevkli bir proje sürecini paylaştıkları öğrencilerin görüşlerinden de anlaşılmaktadır.

Ayrıca, öğrencilerle yürütülen araştırma projelerinde proje oluşturmak için gerekli araç-gerecin temini ve ekonomik açıdan maliyetinin öğretmenler için önemli bir sorun olabileceği bilinmektedir (Demirhan, 2002). Bu çalışmada, öğretmen tarafindan proje uygulamasını zorlaştıracak muhtemel durumları önleyebilmek için proje sürecinin başından bu hususlar da dikkate alınarak proje konusu öğretmen-mentor etkileşimi aracılığı ile tasarlanmıştr. Mentorlük süreciyle, öğretmene gerekli deney malzemelerinin temininde ve deneyin uygulanması konularında bilgi ve beceri konusunda gerekli olan destek sağlanmıştr.

Alan yazında proje tabanlı öğretim yönteminin okul dışı öğrenme ortamlarında öğrencilerin çalışmasına olanak sağlayan bir yöntem olduğuna dair bulgular sunan çalışmalar mevcuttur. Örneğin; Solomon (2003), proje tabanlı öğretim yönteminin öğrencilerin araştırma için müzelere, kütüphanelere, uzman kişilere ve diğer fiziksel alanlara ulaşımasını sağladığını söyler. Buna uyumlu olarak; Simkins, Cole, Tavalin ve Means (2002) ise, bir orman ya da yetenek sınıf, ofis, laboratuar, müze ya da hayvanat bahçesi gibi öğrenme ortamlarında, öğrenciler dört duvar arasında sınırlandırılmadığı için hayatla ilgili gerçek konuların tartı̧ılarak daha anlamlı öğrenme sağlanacağını belirtmişlerdir. Bu çalışmada, Öğretmenin okul dışı ortamlardan yararlanması konusunda bilgi ve erişim desteği mentor aracılığı ile gerçekleşmiştir. Bu sayede öğrenciler günlük rutinleri dışına çıkabilmiş; hastane ortamında araştırma yapma olanağı bulmuşlar ve üstelik bu vesile ile kendilerini değerli hissettiklerini de söylemişlerdir.

\section{Sonuçlar}

Bu araştırma, BILMER Mesleki Gelişim Projesi (Köseoğlu, 2018) kapsamında yapılan BíLMER hizmet içi eğitimçalıştaylarına katılan bir öğretmenin bu eğitimden sonra proje ekibinden aldığı mentorlük desteği ile yürüttüğü okul dışı ortamlarda proje tabanlı öğrenme sürecinin incelenmesini ve bu sürecin özellikle öğrencilerin çeşitli yönlerden gelişim ve değişimlerine etkisini ortaya çıkarmayı hedeflemiştir. Öğrenciler öğretmen tarafindan uygulama ortamında gözlemlenmiş, öğrenciler ile görüşmeler yapılmış, proje süresince de günlük tutmaları istenmiştir. Veri analizleri öğrencilerin kavramsal/bilişsel, duyuşsal, bilimsel araştırma ve bilimin doğası ile ilgili anlayışlar, disiplinler arası ilişkiler ve çevreye duyarlılık konusunda ciddi kazanımlar elde ettiklerini ortaya koymuştur.

Öğretmen, öğrencilerine bu kazanımları sağlama sürecinde kendisine verilen mentor desteğinin yerinin ciddi önemi olduğunu ifade etmiştir. Bu süreçte hem öğrenciler hem de öğretmen proje tabanlı öğrenme, okul dışı öğrenme ortamları ve bilimin doğası ve işleyişi konusunda beslenmiştir. Öğretmenlerin mentorlük sürecinden bilişsel ve duyuşsal alanlarda desteklendiklerine dair James vd. (2018) de benzer sonuçlar raporlamıştır. Aynı şekilde Fricke vd. (2008) de, mentorlük sürecinin öğretmenlerin ve öğrencilerin kendilerine olan güvenlerinin ve öğretime olan inançlarının gelişmesine firsat sağladığını dile getirmiştir. Çalışmanın bulguları, şüphe götürmez biçimde öğrencilerin duyuşsal alanda da önemli kazanımları olduğunu ortaya koymuş ve çalışma sürecinde öğrencilerin coşkularının arttı̆ı, işlerini daha severek yaptıkları sonucuna varılmıştr. Nitekim Mukeredzi'de (2017) bir çalışmasında, mentorlük sürecinden katlımcıların pek çok noktada yararlandığını, öğrencilerin coşkularının arttı̆ını, yaptıkları işi severek yaptıklarını, çalışma tutkusu geliştirdiklerini ifade etmiştir. Ayrıca, bu araştırmada örnek olayı oluşturan öğrencilerin katıldığı Proje Tabanlı Öğrenme sürecinin, çeşitli okul dışı öğrenme ortamlarında deneyimledikleri kalıcı ve gerçek dünya uygulamalarıyla ilgili öğrenme aktiviteleri sayesinde, öğrencilerin bilimle ilgili tutumları üzerinde önemli ölçüde etkili olduğu görülmüştür. Çalışmada incelenen Semra ve Elif kod adlı Öğrencilerin bilime yönelik olumlu tutum geliştirdiklerini gösteren bu sonuçlar, Şentürk ve Özdemir (2014) in sonuçları ile uyum göstermektedir. Bunların ötesinde, bilimin doğası ile ilgili konularda da bu öğrencilerde gelişmeler olduğu bulunmuştur. Bilim insanlarının yaratıcılık, hayal gücü ve düşünme alışkanlıkları gibi bireysel farklılıklarının, bilimsel süreçlerdeki sonuçları nasıl etkilediğine dair öğrencilerin, bulgular başığında verilen örneklerden görüleceği üzere, önemli somut kazanımlar edindiği tespit edilmiştir. Sonuç olarak, bu araşttrmada Mentorlük desteği alan Öğretmenin kazanımları ve bu öğretmenin danışmanlığında projelerini yürütme sürecinde öğren- 
cilerin kazanımları ile ilgili bulgular göz önüne alındığında, Strong vd. (2001)'in iddia ettiği gibi, öğrencilerin gelişiminin öğretmenlerinin mesleki gelişimleriyle ne kadar ilişkili olduğu tezinin de desteklenerek güçlendiğini söyleyebiliriz.

Tekin ve Ayas (2002), meslekteki bazı öğretmenlerin hizmet içi kurslarla ilgili olumlu düşündüklerini ve yeni yaklaşımları kapsayan kurslara intiyaçları olduğunu ortaya çıkarmışlardır. Sezgin, Koşar ve Er (2014) da çalışmalarında, öğretmenlerle okullarında iş birliği yapılarak onların mesleki gelişimlerinin desteklenmesi yönündeki uygulamaların halen yetersiz olduğunu belirtmişler ve okullarda yönetici ve öğretmenlerin mesleki ve sosyal gelişimlerinde mentorlük sürecinin önemli olduğuna dikkat çekmişlerdir. Ayrıca, James vd. (2018) tarafindan yapılan bir çalışmada da, öğretmen ve mentorün işbirliğine dayalı etkileşim içinde yürüttükleri çalışma süreçlerinin, öğretmen yetiştirme programlarına pratik ve faydalı bir araç sunduğu ifade edilmektedir. Bilmer projesi modülleri öğretmenlerin intiyaçları doğrultusunda tasarlamış olup; okul dışı ortamlara uygun pedagojiler ve bilimin doğasının çeşitli boyutları, bu çalışmadaki Öğretmenin katıldığı eğitim de da yoğun olarak ve işbirlikli bir biçimde ele alınmıştır. Öğretmen katıldığı çalıştaydan ve sonrasında aldığı Mentorlük sürecinden etkili bir şekilde faydalandığını ortaya koyarak, Huling ve Resta (2001)'nın çalışmalarında vurguladıklarına benzere şekilde, mesleki yeterlik, yansıtıcı uygulama, yenilenme, psikolojik fayda, işbirliği, sorgulama becerisi geliştirme gibi çeşitli açılardan pek çok yarar sağlamıştı. Sonuç olarak, bu araştırmanın bulgularıyla, öğretmenlerin mesleki gelişimine yönelik programların amaçlarına ulaşabilmeleri için, BiLMER Mesleki Gelişim Modelinde olduğu gibi, öğretmenlere verilecek eğitimlere mentorlük modülü gibi bir eğitim modülünün de dâhil edilmesi gerektiğinin önemi verilere dayandırılarak gösterilmiştir. Öğretmen yetiştirme programlarına, mentorlük uygulamalarının sistematik ve sürdürülebilir bir şeklide entegrasyonu nitelikli öğretmen yetiştirme konusunda olumlu kazanımlar sağlayabilir. Çalışmada, BiLMER öğretmen mesleki gelişim programı kapsamında Öğretmene verilen Mentorlük desteği sayesinde, öğrencilerle yürütülen uzun soluklu bir proje tabanlı uygulama süreci sorunsuz ilerlemiş; Öğretmen öğrencilerini hedeflediği noktaya getirebilmiştir. Hatta bulgular başlığında açıklandığı gibi, öğrenciler kariyer tercihlerini proje sürecindeki uygulamalar doğrultusunda belirlemişlerdir. Bu tespitler, söylem noktasında kalmamış, devamında öğrencilerden birisi alanını, diğeri de mevcut okulunun onu fen alanında istediği mesleklere götürmede yetersiz kalacağını düşünerek okulunu değiştirmiştir.

Bu araştırmada hizmet içi eğitimlerin, yeni yaklaşımları kullanıldığı takdirde etkili olabileceğine dair tespitleri doğrulayacak veriler ortaya çıkmıştrr. Önen, Mertoğlu, Saka ve Gürdal (2010)'a göre, hizmet içi eğitimin bir hedefi de öğretmenlerin performans becerisini, profesyonel bilgisini, kişisel veya genel eğitimini geliştirmek, deneyim ve tecrübelerini zenginleştirmektir; bu zemin sağlandığında öğretmen öğrencilerine çeşitli yönlerden amaçlanan nitelikleri kazandırabilecektir. BiLMER mesleki gelişim modeli, öğretmenlere gerekli pedagojik desteği sunarak okul dışı öğrenme ortamlarının verimli kullanıımasını desteklemektedir. Nitekim çalışmanın bulguları da, söz konusu Öğretmenin katıldığı çalıştayın ve sonrasında proje yürütücüsünden aldığı düzenli mentorlük desteğinin etkisiyle, çeşitli pedagojik konularda ilgisinin ve anlayışının geliştiğini göstermektedir. Bu sonuç, Darling-Hammond vd. (2009) tarafindan yapılan bir çalışmada yazarların, "öğretmenler, mesleki öğrenmelerinin etkili olabilmesi için öğretmen eğitimcileriyle sürekli diyalog kurarak ve öğrencilerin performanslarını inceleyerek, daha etkili öğretim uygulamaları geliştirebilirler" şeklinde ifade ettikleri görüşlerini de kanıtlar niteliktedir. Bunlara ek olarak, Öğretmen mentorlük sürecinde aldığı desteğin, öğrencilerine projelerinde rehberlik ederken yaşadığı sorunların üstesinden gelmesinde çok faydalı olduğunu ifade etmiştir. Baki ve Bütüner (2009) de, öğrencilerine rehberlik ederken sorun yaşaması konusunda öğretmen eksikliklerinin mentorlük süreciyle giderilebileceğini ifade ederler. Ayrıca bu örnek olay araştırmasında, bir öğretmenin bilimsel içerik ve pedagojik yaklaşımlar gibi çeşitli konularındaki gelişiminin, sadece sınıf içi performansında değil, aynı zamanda öğrencilerinin bilimsel içerikle ilgili anlayışlarında ve bilime yönelik tutumlarında da olumlu yönde etkileri olduğu sonucuna varılmıştır. Bu sonuç, Pecore vd. (2013) ün, öğretmen gelişiminin öğrenci üzerinde olumlu etki yaratacağı konusundaki görüşü ile uyumlu olup bu iddiayı desteklemektedir.

\section{Öneriler}

Bu çalışmanın bulgularına dayanarak, Bilmer Modeli mesleki gelişim kapsamında verilen mentorlük eğitimlerinin, katılımcı Öğretmenimiz üzerinde ve dolayısı ile öğrencileriyle proje tabanlı kimya öğretim uygulamalarını yürütürken öğrencileri üzerinde çok yönlü bir etkisi olduğu görülmektedir. Öğrenci projeleri, aslında tasarım ve kurgular açısından değişime açık düşünce yapılarıdır ve proje tabanlı öğrenme yaklaşımında öğretmenin en önemli rolü, öğrencilerinin zihinsel yapısını sürekli olarak yeniden gerektiği şekilde örgütlenmesini sağlayabilmektir. Semra ve Elif ile haftada 4 saat, 20 hafta süreyle yürütülen proje çalışmalarında, öğrencilerin sorumluluk almaları, seçimler yapmaları ve inisiyatif kullanmaları için onlara firsatlar (bakınız: Filippatou ve Kaldi, 2010; Korkmaz ve Kaptan, 2001) veren çeşitli çalışmalar yürütülmüştür. Bu araştırma neticesinde, öğrencilere benzeri öğrenme ortamları yaratabilme konusunda üniversite ve öğretmenlerin daha fazla etkileşimde olması gerektiği önerilmektedir. Öğretmenin mesleki olarak gelişmesi için sistematik şekilde bir kurumdan destek alması önemli bir ihtiyaç haline gelmiştir.

Araştrrmada incelen örnek olayda mentorlük yapılan öğretmenin kendine sunulan firsatlar sürecini iyi yönetmesi sonucunda, öğrencilerinin ikisi de yaşadıkları proje tabanlı öğrenme sürecinden bulgular başlığında ayrıntıları açıklanan

| Kastamonu Eğitim Dergisi, 27(5), 2019| 
çok yönlü kazanımlar edinmiştir. Özellikle bilimin doğası ve bilimsel süreçler gibi konularda öğrencilerin somut kazanımları söz konusudur. Bu nedenlerle, yine öğretmenlere mentorlük desteği alarak öğrencileri ile proje tabanlı öğrenme çalışmaları yürütmeleri önerilmektedir; böylece öğrencilerinin bilime olan ilgi, tutum ve bilimin doğası ile ilgili anlayışlarının gelişeceği zevkli bir süreci de paylaşmış olacaklardır. Bir örnek olay çalışması ile ilgili sınırlılıkları olan bu araştırmadan hareketle, fen eğitimcileri gelecekte yapacakları araştrmalarda mentorlük desteği alan öğretmenler ile almayan öğretmenlerin aynı konudaki uygulamalarını takip ederek sonuçları karşılaştırabilirler. Sonuç olarak öğretmen mesleki gelişimin programlarının etkili ve sürdürülebilir olması için öğretmelere ihtiyaç hissettikleri konularda alan eğitimcileri tarafindan etkili bir mentorlük desteğinin verilmesinin önemli olduğu ve bu sürecin öğrencilerin çeşitli açılardan olumlu kazanımlar edinmesine yol açacağı söylenebilir.

Teşekkür: Bu çalışma, 114K646 numaralı proje kapsamında Türkiye Bilimsel ve Teknolojik Araştırma Kurumu (TÜBITAK) tarafindan desteklenen 1001 Araştırma Projesi kapsamında hazırlanmış olup sağlanan destek için TÜBiTAK'a teşekkür ederiz.

\section{Kaynakça}

Ajzen, I. (1985). From intentions to actions: A theory of planned behavior. In J. Kuhl \& J. Beckman (Eds.), Action control: From cognition to behavior (pp. 11-39). New York: Springer-Verlag.

Akçamente, G., Aslan, B., \& Dinçer, Ç. (2010). Uygulama öğretmenlerinin mentorlük becerilerinin değerlendirilmesi. Uluslararası Öğretmen Yetiştirme Politikaları ve Sorunları Sempozyumu II 16-18 Mayıs 2010 - Hacettepe Üniversitesi, Beytepe-ANKARA.

Akerson, V. L., Abd-El-Khalick, F. S., \& Lederman, N. G. (2000). Influence of a reflective activity-based approach on elementary teachers' conceptions of the nature of science. Journal of Research in Science Teaching, 37, 295-317.

Aslan, B. \& Öcal, S. D. (2012). A Case Study on Mentoring in a Teacher Development Program. Journal of Education and Future, 2, 31 - 48.

Astor-Jack, McCallie, \& Balcerzak (2007). Academic and Informal Science Education Practitioner Views About Professional Development in Science Education. Science Teacher Education, 604-628.

Avraamidou, L. (2014). Studying science teacher identity: Current insights and future research directions. Studies in Science Education, 50, 145-179. https://doi.org/10.1080/03057267.2014.937171.

Avraamidou, L. \& Zembal-Saul, C. (2010). In search of well-started beginning science teachers: Insights fromtwo first-year elementary teachers. Journal of Research in Science Teaching, 47, 661-686.

Baki, A. \& Bütüner S. Ö. (2009), Kırsal Kesimdeki Bir Đlköğretim Okulunda Proje Yürütme Sürecinden Yansımalar, Education Online, 8(1), 146-158, Đlköğretim Online, 8(1), 146-158, [Online]: http://ilkogretim-online.org.tr, 26.05.2009.

Borko, H. \& Putnam, R. (1998). Professional development and reform-based teaching: Introduction to the theme issue. Teaching and Teacher Education, 14(1), 1-3.

Blank, R. K. N. (2010). De las Alas, and Society for Research on Educational Effectiveness. Effects of teacher professional development on gains in student achievement: How meta analysis provides scientific evidence useful to education leaders. Washington, DC: Council of Chief State School Officers.

Cole, M. (1996). A multilevel methodology for cultural psychology. In Cultural psychology: A once and future discipline (pp. 286-325). Cambridge, MA: Belknap Press.

Daresh, J.C. (2003). Teachers Mentoring Teachers: A Practical Approach to Helping New and Experinced Staff. California: Corwin Pres.

Darling-Hammond, L., Wei, R. C., Andree, A., \& Richardson, N. (2009). Professional learning in the learning profession. - Washington, DC: National Staff Development Council.

Demirhan, C. (2002). Program Geliştirmede Proje Tabanlı Öğrenme Yaklaşımı. Hacettepe Üniversitesi, Yayımlanmamış Yüksek Lisans Tezi, Ankara.

Demirel, Ö. (2005). Proje Tabanlı Öğrenme, Kuramdan Uygulamaya Eğitimde Program Geliştirme. PegemA Yayıncılık, Ankara.

Drago-Severson, E. (1994). What does "staff development" develop? How the staff development literature conceives of adult growth. Cambridge, MA: Harvard University.

Duran, E. \& Ballone Duran, L. (2005). A model staff development program and its impact on early childhood teachers' self-efficacy. Journal of Elementary Science Education, 17(2), 1-12.

Erdem, M. (2002). Proje tabanlı öğrenme. Hacettepe Üniversitesi Eğitim Fakültesi Dergisi, 22, 172-179. 22 Ağustos 2013 tarihinde http://www.efdergi.hacettepe.edu.tr/yonetim/icerik/makaleler/943-published.pdf sayfasından erişilmiştir

Falk, J. H. ve Dierking, L. D. (1997). School field trips: Assessing their long-term impact. Curator, 40, 211-217.

Feinstein, N. W., \& Meshoulam, D. (2014). Science for what public? Addressing equity in American science museums and science centers. Journal of Research in Science Teaching, 51, 368-394.10.1002/tea. v51.3

Filippatou, D. \& Kaldi, S. (2010). The effectiveness of project-based learning diffuculties regarding academic performance, group work and motivation. International Journal of Special Education, 25(1), 17-26. 14 Şubat 2013 tarihinde http://files.eric.ed.gov/ fulltext/EJ890562.pdf sayfasından erişilmiştir

Forbes, C., \& Davis, E. A. (2008). Development of preservice elementary teachers' curricular identity for science teaching. Science Education, 92, 909-940. 
Friedrichsen, P., Van Driel, J. H., \& Abell, S. K. (2010). Taking a closer look at science teaching orientations. Science Education, 95, 358-376.

Fricke, I., Horak, E., Meyer, L., \& Van Lingen, N. (2008). "Lessons from a Mathematics and Science Intervention Programme in Tswane township schools", South African Journal of Higher Education, 22 (1), 64-77.

Gersten, R., Vaughn, S., Deshler, D., \& Schiller, E. (1997). What we know about using research findings: Implications for improving special education practice. Journal of Learning Disabilities, 30, 466-476.

Gillies, R. M. \& Ashman, A. F. (2000). The effects of cooperative learning on students with learning diffuculties in the lower elemantary school. The Journal of Special Education, 34(1), 19-27.

Grant, M., (2002). Getting A Grip On Project-Based Learning: Theory, Cases and Recommendations. Gutwill, J. P. \& Allen, S. (2012). Deepening Students' Scientific Inquiry Skills During a Science Museum Field Trip, Journal of the Learning Sciences, 21:1, 130181, DOI: 10.1080/10508406.2011.555938.

Hansford, B., Enrich, L.C., \& Tennent, L. 2004. Formal mentoring programs in education and other professions: A review of the literature, Educational Administration Quarterly, 40(4), 518-540.

Harrıson, J, Dymoke, S., \& Pell, T. (2006). Mentoring Beginning Teachers in Secondary Schools: An Analysis of Practice. Teaching and Teacher Education, 22, 1055-1067.

Herron, S. S., Magomo, D., \& Gossard, P. R. (2008). The Wheel Garden: Project Based Learning for Cross Curriculum Education. International Journal of Social Sciences, 3(1), 44-51.

Huling, L. \& Resta, V. (2001). Teacher Mentoring as Professional Development. ERIC Digest, ERIC Clearing house on Teaching and Teacher Education, Washington DC

İlğan A. (2013). Öğretmenler İçin Etkili Mesleki Gelişim Faaliyetleri , Uşak Üniversitesi Sosyal Bilimler Dergisi (2013) Özel Sayı, 41-56.

James, M. W. V., , Beth Maloch, H., Vlach, S. K., Taylor, L. A., Svrcek, N. S., Dejulio, S., Martinez, A. , \& Lavender, H., (2018). "Coaching elementary preservice teachers: Hybrid spaces for cooperating teachers and university field supervisors to collaborate", International Journal of Mentoring and Coaching in Education, Vol. 7 Issue: 4, pp.357-372.

Kartal, S. E., Özdemir, T, Y., \& Yirci, R. (2017). Mentorship needs of early career teachers working in rural regions. Turkish Journal of Education, 6(1): DOI: 10.19128/turje.284833

Korkmaz, H. \& Kaptan, F. (2001). Fen eğitiminde proje tabanlı öğrenme yaklaşımı. Hacettepe Üniversitesi Eğitim Fakültesi Dergisi, 20, 193-200. 23 Ocak 2013 tarihinde http://www.efdergi.hacettepe.edu.tr/makale_goster.php?id=1005 sayfasından erişilmiştir.

Köseoğlu, F. (2018). Bilim Merkezlerinin Bilim-Toplum İletişiminde ve Bilim Eğitiminde Etkinliğini Arttrmaya Yönelik Bir Öğretmen ve Eğitmen Mesleki Gelişim Modeli. Yanınlanmamış Tübitak 1001 Projesi (114K646) Raporu.

Krajcik, J. S., Blumenfeld, P. C., Marx, R. W. \& Soloway, E. (1994). A collaborative model for helping middle grade science teachers learn project-based instruction. The Elementary School Journal, 94(5), 483-497. 10 Şubat 2014 tarihinde http://www.jstor.org/ stable/pdf/1001838.pdf?_=1467544901740 sayfasından erişilmiştir.

Laverick., D. M. (2016). Professional Development through Mentoring, Mentoring Processes in Higher Education. pp 35-46.

Loucks-Horsley, S. \& Matsumoto, C. (1999). Research on professional development for teachers of mathematics and science: The state of the scene. School Science and Mathematics, 99(5), $258-271$.

Maurer, M. J. (2000). Professional development in careerandtechnicaleducation. Inbrief: Fastfactsforpolicyandpracticeno. 7. Columbus, OH: NationalDissemination Center forCareerand Technical Education, The Ohio StateUniversity (ED 448318 ).

Marx, R. W., Blumenfeld, P. C., Krajcik, J. S., \& Soloway, E. (1997). Enacting project-based science: Challenges for practice and policy. Elementary School Journal, 97, 341-358.

Miranda, R. 2012. Urban high school teachers' beliefs concerning essential science teaching dispositions. Science Educator 21(1):44-50.

Mukeredzi, T. G. (2017). Mentoring in a Cohort Model of Practicum: Mentors and Preservice Teachers' Experiences in a Rural South African School. SAGE Open. https://doi.org/10.1177/2158244017709863.

National Research Council, (1996). National science education standards. Washington, DC: National Academy Press.

National Research Council, (2000). Inquiry and the national science education standards. Washington, DC: National Academy Press.

Neuman, W. L. (2006). Social research methods: Qualitative and quantitative approaches (6th ed.). Boston: Pearson/AandB.

Osborne, J., Simon, S., \& Collins, S. (2003). "Attitudes towards science: A review of the literature and its implications", International Journal of Science Education, 25, 1049-1079. doi: 10.1080/0950069032000032199.

Önen, F; Mertoğlu, H., Saka, M. \& Gürdal, A. (2010). Hizmet İçi Eğitimin Öğretmenlerin Proje ve Proje Tabanlı Öğrenmeye illişkin Bilgilerine ve Proje Yapma Yeterliklerine Etkisi: Öpyep Örneği. Ahi Evran Üniversitesi Eğitim Fakültesi Dergisi, 11(1), 137-158

Pace, S. \& Tesi, R. 2004. “Adults' perception of field trips taken within grades K-12: Eight case studies in the New York metropolitan area", Education, 125(1), 30-40.

Pecore, J. L., Kirchgessner, M. L., \& Carruth, L. L. (2013). Changes in science content knowledge and attitudes toward science teaching of educators attending a zoo-based neuroscience professional development. Clearing House, 86(6), 238-245. doi: 10.1080/00098655.2013.826527.

Rhodes, C. \& Beneicke, S. (2002). Coaching, mentoring and peer-networking: challenges for the management of teacher professional development in schools, Journal of In-Service Education, 28:2, 297-310.

Saban, A. (2002). Öğrenme Öğretme Süreci. Ankara: Nobel Yayın Dağıtım. 
Scott, D. C. \& Weeks, P. A. (1996). Collaborative staff development. Innovative Higher Education, 21, 101-111.

Simkins, M., Cole, K., Tavalin F. and Means, B. 2002. Increasing student-learning through multimediaprojects. ASCD, USA,

Simmons, D. C., Kuykendall, K., King, K., Cornachione, C., \& Kameenui, E. J. (2000). Implementation of a schoolwide reading improvement model: "No one ever told us it would be this hard!". Learning Disabilities Research and Practice, 15, 92-100.

Stein, M. K., Schwan Smith, M., \& Silver, E. A. (1999). The development of professional developers: Learning to assist teachers in new setting

Scribner, S. (1984). Studying working intelligence. In B. Rogoff \& J. Lave (Eds.), Everyday cognition: Its development in social context (pp. 9-40). Cambridge, MA: Harvard University Press.

Sezgin, F., Koşar, S., \& Er, E. (2014). Examining mentoring in the training of School administrators and teachers. Kastamonu Üniversitesi Kastamonu Eğitim Dergisi 2014, 22 (3) 1337-1356.

Sparks, D. \& Loucks-Horsley, S. (1989). Five models of staff development for teachers. Journal of Staff Development, 10 (4), $40-57$.

Strong, R., Silver, H., \& Perini, J. (2001). Making students as important as standards. Educational Leadership, 59(3), 56 - 61.

Şentürk, E., \& Özdemir, Ö. F. (2014). "The effect of science centres on students' attitudes towards science", International Journal of Science Education, Part B: Communication and Public Engagement, 4, 1-24. doi: 10.1080/21548455.2012.726754.

Tekin, S., \& Ayaş, A. (2002). Kimya Öğretmenlerinin Profesyonel Gelişim Süreçleri Ve Hizmet İçi Eğitime Bakış Açıları. 10 Eylül 2017 https://www.researchgate.net/publication/265938945_sayfasından erişilmiştir.

Thomas, J. W. (2000). A review of research on project-based learning. Autodesk Foundation PBL. http:// www.bie.org/index.php/ site/resource/item27/.

Wertsch, J.V. (1985). Vygotsky and the social formation of mind. Cambridge, MA: Harvard University Press.

Wurdinger, S., Haar, J., Hugg, R. \& Bezon, J. (2007). A qualitative study using projectbased learning in a mainstream middle school. Improving schools, 10(2), 150-161. 15 Şubat 2013 tarihinde http://imp.sagepub.com/content/10/2/150.short sayfasından erişilmiştir

Vygotsky, L.S. (1978). Mind in society: The development of higher psychological processes, Cambridge, MA: Harvard University Press.

Yıldırım, R, \& Yılmaz, E. (2013). Okul Yöneticilerinin Mentorluk Rollerinin Okulun Akademik Başarısı ve Bazı Değişkenler Açısından İncelenmesi. Muğla Sıtkı Koçman Üniversitesi Sosyal Bilimler Enstitüsü Dergisi, Sayı 30, 2013 Bahar, 98 - 119.

Yurtluk, M. (2003). Proje tabanlı öğrenme yaklaşımının matematik dersi öğrenme süreci ve öğrenci tutumlarına etkisi. Yüksek Lisans Tezi, Hacettepe Üniversitesi Sosyal Bilimler Enstitüsü, Ankara.

\section{Ekler}

\section{Ek-1. Öğrencilerin Proje Raporundan, Kekik Bitkisinden Uçucu Yağların Ekstraksiyonu ile ilgili Bölümden Alınan} Bir Kısım

\section{EKTRAKSIYON YÖNTEMI}

Ekstraksiyon bir ayırma işlemidir. Analitik uygulamalardan ekstraksiyon genellikle bir maddenin tayinine etki eden maddeleri fazlardan birinde bırakıp tayin edilecek maddeyi diğer faza seçimli olarak geçirmek amacıyla uygulanır.

Ekstraksiyon işleminin teorik dayanağı Nerst'in “Dağılma Kanunu”dur. Bu kanuna göre, eğer bir madde bir sistemin birden fazla fazı içinde mevcut ise, sistemin dengesi için, bu maddenin çeşitli fazlardaki konsantrasyonları arasında belirli bir sıcaklıkta belirli bir oran bulunmalıdır. Buna göre birbirleri ile hiç karışmayan ya da az oranda karışan iki sıvının oluşturduğu bir sisteme, her iki sıvı içinde de çözünebilen bir madde eklendiğinde, bu maddenin iki sıvıdaki konsantrasyonlarının birbirlerine oranı sabit olacaktır.

Katıların ekstraksiyonu genellikle uzun zaman aldığı için sürekli ekstraksiyon yöntemleri tercih edilir. Maddenin kat içinden difüzlenmesi yavaş bir işlem olduğu için kat örnek ince toz haline dönüştürüldükten sonra ekstrakte edilmelidir. Böylece maddenin çözücü sıvıyla daha fazla teması sağlanır.

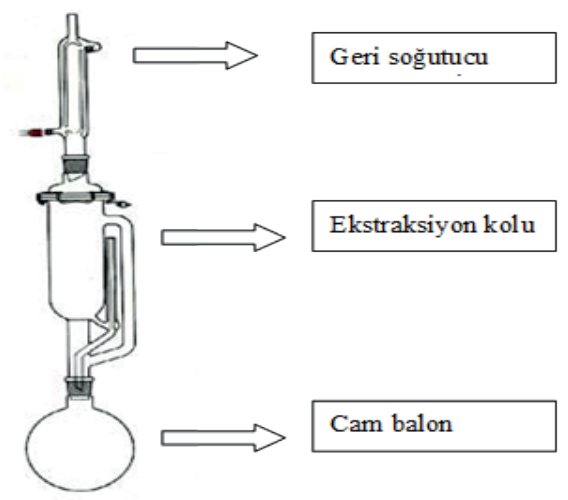

Şekil 1. Sokshlet Ekstraksiyon Cihazı 
Sokshlet Ekstraksiyon Cihazında cam balona çözücü olarak kullanılacak kimyasal madde konulur ve ısıtıcı yardımıyla bu maddenin buharlaşması sağlanır. Buharlaşan çözücü ekstraksiyon kolundan geçerek geri soğutucuya ulaşır. Geri soğutucuda yoğunlaşarak sıvı hale gelen çözücü tekrar ekstraksiyon kolonuna gelerek kartuş içerisinde bulunan bitkideki bazı maddeleri çözerek cam balona geri döner. Bu işlem sürekli tekrarlanarak ekstraksiyon tamamlanmış olur.

\section{Ek-2}

Öğrencilerin özel bir hastanenin mikrobiyoloji laboratuarında patojen mikroorganizma suşları üzerinde disk difüzyon yöntemi ile uyguladıkları kekik ekstraktları için elde ettikleri sonuçlarla ilgili olarak Proje Raporlarında verdikleri tablo.

Tablo 3 - Farklı Çözücülerle Elde edilen Kekik Ekstraktlarında Patojenlerin Üremesiyle ilgili Zon Çapları

\begin{tabular}{|c|c|c|}
\hline \multicolumn{3}{|c|}{ Zon çapları (farklı ekstraktlar için)(mm) } \\
\hline Patojen bakteri & $\begin{array}{c}\text { Etil alkol ile elde edilen kekik } \\
\text { ekstrakt }\end{array}$ & Saf su ile elde edilen kekik ekstrakt \\
\hline 1.STAPHYLOCOCCUS AURENS & 29 & 9 \\
\hline 2.E.COLI & 21 & 0 \\
\hline 3.PSEUDOMANOS AUREGONOS & 9 & 0 \\
\hline
\end{tabular}

